\title{
Ion mobility spectrometry-mass spectrometry (IMS-MS) for on- and offline analysis of atmospheric gas and aerosol species
}

\author{
Jordan E. Krechmer ${ }^{1,2}$, Michael Groessl ${ }^{3}$, Xuan Zhang ${ }^{4}$, Heikki Junninen ${ }^{5}$, Paola Massoli ${ }^{4}$, Andrew T. Lambe ${ }^{4,6}$, \\ Joel R. Kimmel ${ }^{3,4}$, Michael J. Cubison ${ }^{3}$, Stephan Graf ${ }^{3}$, Ying-Hsuan Lin ${ }^{7, a}$, Sri H. Budisulistiorini ${ }^{7, b}$, Haofei Zhang ${ }^{7, c}$, \\ Jason D. Surratt ${ }^{7}$, Richard Knochenmuss ${ }^{3}$, John T. Jayne ${ }^{4}$, Douglas R. Worsnop ${ }^{4,5}$, Jose-Luis Jimenez ${ }^{1,2}$, and \\ Manjula R. Canagaratna ${ }^{4}$ \\ ${ }^{1}$ Cooperative Institute for Research in Environmental Sciences (CIRES), Boulder, Colorado 80309, USA \\ ${ }^{2}$ Department of Chemistry and Biochemistry, University of Colorado, Boulder, Colorado 80309, USA \\ ${ }^{3}$ TOFWERK, 3600, Thun, Switzerland \\ ${ }^{4}$ Center for Aerosol and Cloud Chemistry, Aerodyne Research, Billerica, Massachusetts 01821, USA \\ ${ }^{5}$ Department of Physics, University of Helsinki, 00014, Helsinki, Finland \\ ${ }^{6}$ Chemistry Department, Boston College, Chestnut Hill, Massachusetts 02467, USA \\ ${ }^{7}$ Department of Environmental Sciences and Engineering, Gillings School of Global Public Health, \\ The University of North Carolina at Chapel Hill, North Carolina, USA \\ ${ }^{a}$ now at: Michigan Society of Fellows, Department of Chemistry, University of Michigan, \\ Ann Arbor, Michigan, USA \\ ${ }^{b}$ now at: Earth Observatory of Singapore, Nanyang Technological University, Singapore \\ ${ }^{c}$ now at: Department of Environmental Science, Policy, and Management, University of California, \\ Berkeley, California, USA
}

Correspondence to: Manjula R. Canagaratna (mrcana@aerodyne.com)

Received: 18 April 2016 - Published in Atmos. Meas. Tech. Discuss.: 29 April 2016

Revised: 29 June 2016 - Accepted: 1 July 2016 - Published: 25 July 2016

\begin{abstract}
Measurement techniques that provide molecularlevel information are needed to elucidate the multiphase processes that produce secondary organic aerosol (SOA) species in the atmosphere. Here we demonstrate the application of ion mobility spectrometry-mass spectrometry (IMS-MS) to the simultaneous characterization of the elemental composition and molecular structures of organic species in the gas and particulate phases. Molecular ions of gas-phase organic species are measured online with IMS-MS after ionization with a custom-built nitrate chemical ionization (CI) source. This CI-IMS-MS technique is used to obtain timeresolved measurements $(5 \mathrm{~min})$ of highly oxidized organic molecules during the 2013 Southern Oxidant and Aerosol Study (SOAS) ambient field campaign in the forested SE US. The ambient IMS-MS signals are consistent with laboratory IMS-MS spectra obtained from single-component carboxylic acids and multicomponent mixtures of isoprene and monoterpene oxidation products. Mass-mobility correla-
\end{abstract}

tions in the 2-D IMS-MS space provide a means of identifying ions with similar molecular structures within complex mass spectra and are used to separate and identify monoterpene oxidation products in the ambient data that are produced from different chemical pathways. Water-soluble organic carbon (WSOC) constituents of fine aerosol particles that are not resolvable with standard analytical separation methods, such as liquid chromatography (LC), are shown to be separable with IMS-MS coupled to an electrospray ionization (ESI) source. The capability to use ion mobility to differentiate between isomers is demonstrated for organosulfates derived from the reactive uptake of isomers of isoprene epoxydiols (IEPOX) onto wet acidic sulfate aerosol. Controlled fragmentation of precursor ions by collisionally induced dissociation (CID) in the transfer region between the IMS and the MS is used to validate MS peak assignments, elucidate structures of oligomers, and confirm the presence of the organosulfate functional group. 


\section{Introduction}

Organic aerosol (OA) species constitute a major fraction of airborne particles globally, comprising $20-90 \%$ of fine particle mass in many regions (Hallquist et al., 2009; Murphy et al., 2006; Zhang et al., 2007) and is either directly emitted into the atmosphere in the particle phase (primary $\mathrm{OA}, \mathrm{POA}$ ) or formed from gas-to-particle conversion processes (secondary OA, SOA). Estimates of global SOA budgets from current atmospheric chemistry models are uncertain (Spracklen et al., 2011; Tsigaridis et al., 2014). OA and its gas-phase precursors comprise thousands of unique molecules (Goldstein and Galbally, 2007; Mazzoleni et al., 2012). Obtaining comprehensive and speciated measurements of all of these organic molecules strains the limits of conventional instrumentation (Hallquist et al., 2009; Nozière et al., 2015).

Ultra-high-resolution mass spectrometry (UHRMS; mass resolution $>50000$ ) techniques, such as FTICR-MS (Fourier transform ion cyclotron resonance mass spectrometry) or Orbitrap-type instruments (Mazzoleni et al., 2012), can be combined with direct infusion techniques to characterize thousands of organic compounds simultaneously. Direct infusion comprises a number of soft ionization sources, such as electrospray ionization (ESI), which introduce the sample into an ionization source without prior separation. Despite the increase in mass resolution, UHRMS cannot, however, resolve structural isomers without a prior separation step and accurate quantification of observed species is complicated by ion suppression/matrix effects (Nozière et al., 2015). Instruments with MS/MS fragmentation capability (as in a triplequadrupole mass analyzer) can also be used to identify organic molecules, including isomers. Since MS/MS is usually performed by scanning over a narrow range of massto-charge ratios $(m / z)$, these measurements typically have a limited range of species that can be monitored during timeresolved measurements. An authentic standard is also necessary to verify a compound's unique fragmentation pattern.

Thus, molecular-level identification of individual organic species is often achieved by coupling mass spectrometry with a separation technique such as liquid chromatography (LC) or gas chromatography (GC). Reverse-phase (RP) LC followed by mass spectrometry using ESI, a very "soft" ionization technique due to the almost exclusive formation of molecular ions (Gao et al., 2004; Glasius et al., 1999; Iinuma et al., 2004; Surratt et al., 2006), is often used to separate and identify OA constituents. LC/MS methods (and GC/MS) require authentic standards, however, and solvent matrix effects and solvent-analyte reactions can potentially have detrimental effects on the sample (Nozière et al., 2015). GC methods are also inefficient for characterizing aerosol constituents like WSOC because prior derivatization steps are needed to convert these species into volatile derivatives that can be resolved by GC columns. Derivatization methods have been found to degrade species such as oligomers and organosulfates, resulting in misidentification (Hallquist et al., 2009). GC techniques also require heating, which has been shown to decompose some organic species to $\mathrm{CO}_{2}$ or other small molecules (Williams et al., 2016). Recent analytical advances such as the volatility and polarity separator (VAPS) have increased the fraction of WSOC that is amenable to GC/MS analysis without derivatization, but a large portion remains uncharacterized (Martinez et al., 2016).

Ion mobility spectrometry (IMS) is a well-established separation technique, the principles of which were first laid out in 1903 (Thomson, 1903). Previously known as plasma chromatography or gaseous electrophoresis (Karasek, 1974), IMS has gained prominence and utility over the last 15 years with rapidly increasing numbers of commercially available instruments (Eiceman et al., 2013). IMS separates gasphase ions based on a property known as ion mobility, $K$, which is sensitive to molecular structure (i.e., ion size and shape/conformation) and ion-molecule interactions with a buffer gas such as nitrogen, helium, or air. Since IMS separations are based on gas-phase mobility rather than polarity, they are not limited by solvent- or stationary-phase constraints. Thus, IMS can be used to separate species with different structures that are not easily separated by LC and GC techniques. Such species include isomers, which are species with the same atomic composition arranged in different structures, and isobars, which are compounds of different atomic composition but have overlapping mass numbers (McNaught and Wilkinson, 2014). In fact, IMS-MS (IMS separation coupled with mass spectrometric detection of ions) has been demonstrated as a powerful replacement for LC/MS in complex fields of analysis such as lipids, metabolites, water quality, and pharmaceuticals (Dwivedi et al., 2008; Groessl et al., 2015; Jarrold, 2000; Kanu et al., 2008).

In this work we demonstrate the first application of IMSMS for molecular-level analysis of both aerosol- and gasphase atmospheric constituents. All measurements are carried out on a TOFWERK ion mobility spectrometer-time of flight (IMS-TOF) (Thun, Switzerland). We present offline filter analyses of aerosol constituents using an ESI source coupled to an IMS-TOF instrument. Separation of WSOC species and aerosol-phase organosulfate isomers are demonstrated. Collisionally induced dissociation (CID) is used to distinguish chemically bound oligomers from weakly bound clusters and for identification of molecules. We also present measurements of gas-phase species using a custom $\mathrm{NO}_{3}^{-}$ chemical ionization (CI) source coupled to the IMS-TOF. This ion source was used to enable detection of highly oxidized species in the gas phase that are likely to directly condense onto particles (Eisele and Tanner, 1993; Mauldin et al., 1998). Time-resolved online IMS-MS measurements (time resolution of $5 \mathrm{~min}$ ) with this source from a field campaign (SOAS 2013 in Centreville (CTR), Alabama) and laboratory flow reactor studies are discussed. The use of trend lines in the 2-D IMS-MS plots to identify species with related 
molecular structures, even within complex high-resolution mass spectra, is highlighted.

\section{Experimental setup}

\subsection{IMS-MS}

A schematic of the IMS-TOF instrument is provided in Fig. 1a. The IMS cell of the instrument is both pressure and temperature controlled and contains two resistive-coated glass tubes (Kaplan et al., 2010) separated by a BradburyNielsen (BN) ion gate (Bradbury and Nielsen, 1936) along which a uniform electric field is applied (reduced electric field strength approx. 2 Townsend $\left(1 \mathrm{Td}=10^{-21} \mathrm{~V} \mathrm{~m}^{2}\right)$ ). The IMS cell is maintained at or above atmospheric pressure to increase IM resolving power and can be operated between room temperature and $150^{\circ} \mathrm{C}$. Nitrogen $\left(\mathrm{N}_{2}\right)$ is usually used as the buffer gas and IMS pressure can be set between 800 and 1400 mbar.

Ions from an ionization source are pulsed through the BN gate and separated in the $20.5 \mathrm{~cm}$-long drift tube. A clean, dry $\mathrm{N}_{2}$ gas countercurrent flow of 1.2 standard $\mathrm{L} \mathrm{min}^{-1}$ (SLPM at $21^{\circ} \mathrm{C}$ and $101.3 \mathrm{kPa}$ ) is introduced from a liquid $\mathrm{N}_{2}$ dewar into the drift tube to induce ion-neutral collisions. After exiting the drift tube, ions are transferred to the pressure reduction interface (containing two quadrupole ion guides) and through a $0.3 \mathrm{~mm}$ pinhole before being detected with a TOFWERK HTOF time-of-flight mass spectrometer (TOF MS). IMS separation occurs on the millisecond timescale and thus couples well with TOF MS, which operates on a microsecond timescale. IMS-TOF instruments can therefore acquire many mass spectra for each ion mobility spectrum (Kanu et al., 2008). The mass spectral resolution $m / \mathrm{d} m_{50}$ of the instrument is typically 3500-4000 FWHM at $m / z 250$.

As described in the following sections, ions from condensed-phase samples are generated by ESI and from gas-phase samples by a custom online $\mathrm{CI}$ that utilizes $\mathrm{NO}_{3}^{-}$ as a reagent ion. To improve signal intensity, sensitivity, signal-to-noise, and duty cycle, ions are pulsed into the drift region using a multiplexed gating scheme (Zare et al., 2003; Zhang et al., 2014). With multiplexing, the IMS-TOF achieves a $50 \%$ IMS duty cycle (i.e., $50 \%$ of the ions generated could be analyzed), as opposed to $<1 \%$ in standard pulsed mode, leading to an increase in ion transmission of approximately 100-fold. With postprocessing, the IMS resolution $\left(t / \mathrm{d} t_{50}\right)$ routinely exceeds 200 . Data analysis is performed using the data analysis package "Tofware" (version 2.5.3, www.tofwerk.com/tofware) running in the Igor Pro (WaveMetrics, OR, USA) environment. All IMS drift time plots and IMS-MS spectra shown in the manuscript have been postprocessed in the multiplexed domain for reduction of systematic and random noise during the multiplexing process and enhancement of the modulation (Knochenmuss et al., 2013).
The IMS-TOF used in this work can also provide CID analyses in which ions are fragmented immediately after the IMS drift cell and before they are transmitted into the TOF (Kaplan et al., 2010). The information obtained from CID is similar to that obtained from traditional MS/MS measurements, but since CID occurs immediately after ion mobility separation (IMS-CID-MS), it has two key advantages: (1) fragment and precursor ions appear at the same IMS drift time, allowing for easy correlation between fragments and precursor; and (2) CID spectra can be simultaneously obtained over the entire $m / z$ range without need for preselection or limited scanning of mass regions as in traditional MS/MS measurements. For the examples reported in this work, we utilized typical CID potential differences between the exit of the first quadrupole and the entrance of the second quadrupole, ranging from 1 to $30 \mathrm{~V}$.

Drift times measured during any given IMS-MS experiment are dependent on the pressure and temperature of the drift tube. These dependencies as well as the instrument electric field can be accounted for to obtain a related parameter known as reduced mobility, $K_{0}$ :

$K_{0}=\frac{L^{2}}{V t_{\mathrm{d}}} \frac{P}{P_{0}} \frac{T_{0}}{T}$,

where $L$ is the length of the drift tube, $V$ is the applied electric field potential, $t_{\mathrm{d}}$ is the drift time of the analyte, $P$ and $P_{0}$ are the actual and reference pressures, respectively, and $T$ and $T_{0}$ are the actual and reference temperatures, respectively (Eiceman et al., 2013). If the instrument is calibrated and conditions are well controlled, molecular collision cross sections $(\Omega)$ can be extracted from the measured reduced mobilities by using the Mason-Schamp equation (Mason and Schamp, 1958; Mcdaniel and Mason, 1973; Revercomb and Mason, 1975):

$\Omega=\frac{1}{K_{0}} \frac{3 q z}{16 N}\left(\frac{2 \pi}{\mu k T_{\mathrm{eff}}}\right)^{\frac{1}{2}}$,

in which $K_{0}$ is mobility, $q$ is the elementary charge, $z$ is the charge number, $N$ is the neutral gas number density, $\mu$ is the reduced mass of the analyte-buffer gas pair, $k$ is the Boltzmann constant, and $T_{\text {eff }}$ is the effective temperature.

Collision cross sections can be more accurately calculated using a momentum transfer scan law that includes fielddependent corrections for both collisional momentum transfer and collision frequency ( $\alpha$ and $\beta$ terms, respectively) (Siems et al., 2012).

$\Omega=\frac{1}{K_{0}} \frac{3 q z}{16 N}\left(\frac{2 \pi}{\mu k T}\right)^{\frac{1}{2}}\left[1+\left(\frac{\beta_{\mathrm{MT}}}{\alpha_{\mathrm{MT}}}\right)^{2}\left(\frac{v_{\mathrm{d}}}{v_{T}}\right)^{2}\right]^{-\frac{1}{2}}$,

in which $K_{0}$ is mobility, $q$ is the elementary charge, $z$ is the charge number, $N$ is the neutral gas number density, $\mu$ is the reduced mass of the analyte buffer gas pair, $k$ is the Boltzmann constant, $T$ is the standard temperature, $v_{\mathrm{d}}$ is the drift 
velocity, and $v_{T}$ is the thermal velocity (Siems et al., 2012). $\alpha_{\mathrm{MT}}$ and $\beta_{\mathrm{MT}}$ are calculated as follows:

$\alpha_{\mathrm{MT}}=\frac{2}{3}[1+\hat{m} \hat{c}+\hat{M} \hat{h}]$

$\beta_{\mathrm{MT}}=\left[\frac{2}{\hat{m}(1+\hat{m})}\right]^{\frac{1}{2}}$,

where $m$ and $M$ are the ion and neutral masses, respectively, $\hat{m}$ and $\hat{M}$ are the mass fractions of the colliding pair, $\hat{c}$ is the fraction of collisions that cool the ion, and $\hat{h}$ is the fraction of collisions that heat the ion (Siems et al., 2012) .

IMS drift times and mobilities obtained under the same buffer gas conditions are reproducible and transferable. The measured $\Omega$ can be compared with literature or previous experiment values to identify molecular structures without the use of an analytical standard.

\subsection{ESI-IMS-TOF and filter samples}

Ambient filters were collected during the 2013 Southern Oxidant and Aerosol Study (SOAS; https://soas2013.rutgers. edu/) at the Look Rock, TN, USA site (LRK; Budisulistiorini et al., 2015). Detailed description of aerosol filter collection, storage, and extractions during SOAS at the LRK site was described recently by Budisulistiorini et al. (2015). In the current study, an aerosol extract from 16 June 2013 (intensive sample 3, which was collected from 16:00 to 19:00 local time) was used to demonstrate the abilities of ESI-IMS-MS in the chemical characterization of ambient SOA at the molecular level. In addition, laboratory-generated SOA produced from the reactive uptake of authentic trans$\beta$-IEPOX, cis- $\beta$-IEPOX, and $\delta$-IEPOX onto acidified sulfate aerosol under dark conditions were collected onto Teflon filters $(1.0 \mu \mathrm{m}$ pore size, Tisch Environmental, EPA PM 2.5 membrane) for analysis by the ESI-IMS-MS technique. Details of chamber experiments, including filter extraction procedures for Teflon filters and operating conditions, have been previously described by Lin et al. (2012, 2014). Certain isoprene SOA constituents, including the organosulfate derivatives of 2-methylglyceric acid and the 2-methyltetrols, were synthesized in house as recently described by Rattanavaraha et al. (2016) and Budisulistiorini et al. (2015), respectively. Synthesis details for authentic trans- $\beta$-IEPOX, cis- $\beta$-IEPOX, and $\delta$-IEPOX (as a racemic mixture of the diastereomers) were described by Lin et al. $(2012,2014)$ and Zhang et al. (2012). It is noted here that since the multiphase chemistry of IEPOX isomers contributed greatly to the SOA mass at the LRK site (Budisulistiorini et al., 2015), these chamber experiments were used to complement the ESI-IMS-MS results from LRK.

Aerosol filter samples were analyzed offline using an ESI source coupled to the IMS-MS instrument. $5 \mu \mathrm{L}$ of the samples were injected for analysis at a flow rate of $1 \mu \mathrm{Lmin}^{-1}$. The IMS was operated at $50^{\circ} \mathrm{C}$ and 1000 mbar, mass spec- (a)
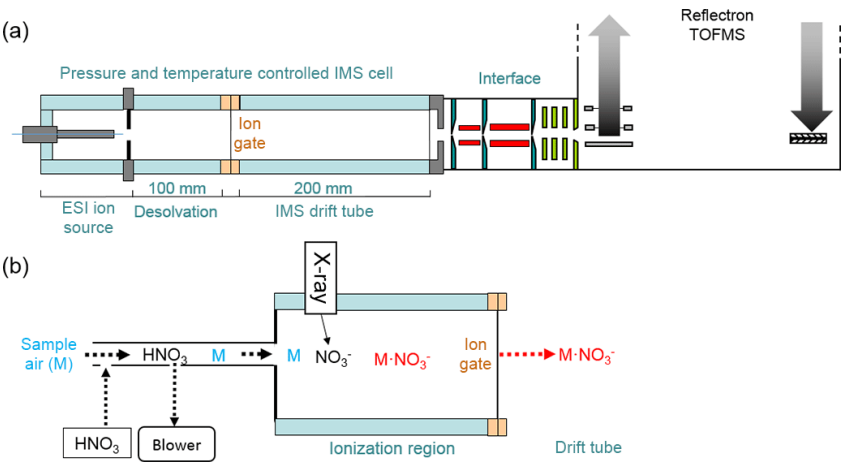

Figure 1. A schematic diagram of the IMS-TOF (a). The instrument can be used with different ionization sources, including the ESI source shown in (a) and the custom-built nitrate-ion chemical ionization source $\left(\mathrm{NO}_{3}^{-}-\mathrm{CI}\right)$ attached to the front end of the desolvation region shown in (b). The diagram is not drawn to scale.

tra were recorded from $m / z 10$ to 1200 in both positive and negative ion mode. ESI potential was at $1600 \mathrm{~V}$.

\section{$2.3 \mathrm{NO}_{3}^{-}$CI-IMS-MS}

In this work gas-phase ions were generated and coupled to the IMS-TOF with a custom-built nitrate ion chemical ionization source (hereafter CI-IMS-TOF). The design constraints on the CI source for this IMS-TOF are (1) ions must be formed at a pressure $\sim 1$ atmosphere (atm) so that they can be directly coupled to the drift tube of the IMS-TOF which is operated at a pressure of about $1 \mathrm{~atm}$ and (2) the ions formed from the CI source must be formed at, or be efficiently transferred into, the high voltage $(\sim 10 \mathrm{kV})$ of the inlet of the IMS-TOF. The main components and operating principles of the source are shown in Fig. 1b. An X-ray ionizer (Hamamatsu, Inc., Japan) was aimed into the reaction/desolvation region to initiate ionization. To provide the precursor for the reagent ion, 5 standard $\mathrm{cm}^{3} \mathrm{~min}^{-1}$ ( $\mathrm{sccm}$ ) of clean, dry $\mathrm{N}_{2}$ gas from the boil-off of a liquid $\mathrm{N}_{2}$ dewar flowed across a glass vial of fuming nitric acid $\left(\mathrm{HNO}_{3}\right)$ into the reaction region.

The nitrate CI mechanism comprised a series of reactions. First, an X-ray emitter initiated an ionization process that resulted in the formation of nitrate ions $\left(\mathrm{NO}_{3}^{-}\right)$from the gasphase nitric acid $\left(\mathrm{HNO}_{3}\right)$. The nitrate ions then clustered with sample molecules to form an ion-molecule cluster:

$(\mathrm{n}+1) \mathrm{HNO}_{3} \rightarrow\left(\mathrm{HNO}_{3}\right)_{\mathrm{n}} \mathrm{NO}_{3}^{-}+\mathrm{H}^{+}$.

The nitric acid-nitrate clusters then collided with analyte molecules in the sample air, initiating ion-molecule reactions that either deprotonated (Eq. 7) or clustered (Eq. 8) with the 
target analytes:

$$
\begin{aligned}
& \left(\mathrm{HNO}_{3}\right)_{\mathrm{n}} \mathrm{NO}_{3}^{-}+\mathrm{HX} \rightarrow\left(\mathrm{HNO}_{3}\right)_{\mathrm{n}}+\mathrm{HNO}_{3}+\mathrm{X}^{-} \\
& \left(\mathrm{HNO}_{3}\right)_{\mathrm{n}} \mathrm{NO}_{3}^{-}+\mathrm{HZ} \rightarrow\left(\mathrm{HNO}_{3}\right)_{\mathrm{n}}+\left(\mathrm{NO}_{3}^{-}\right) \mathrm{HZ},
\end{aligned}
$$

where HX in Eq. (7) must be a highly acidic compound such as sulfuric acid $\left(\mathrm{H}_{2} \mathrm{SO}_{4}\right)$ or methanesulfonic acid (MSA) and $\mathrm{HZ}$ in Eq. (8) is a highly functionalized and oxidized species (Eisele and Tanner, 1993; Jokinen et al., 2012; Mauldin et al., 1998). All of these reactions take place inside a reaction region floated at a voltage above that of the $\mathrm{BN}$ gate. Thus, ions were formed at maximum electrical potential and moved at a steady speed through the drift tube.

The single-chamber design of our $\mathrm{NO}_{3}^{-}$source differs from the source design of Eisele and Tanner (1993) in its lack of concentric sample and sheath flows. As a result, the X-rays directly interact with sample air molecules without time for conversion of all ions to $\mathrm{NO}_{3}^{-}$. While clustering with $\mathrm{NO}_{3}^{-}$ is the dominant ionization mechanism, we also observe additional minor ionization pathways. The most significant of the additional mechanisms is deprotonation via $\mathrm{O}_{2}^{-}$, which primarily produced $[\mathrm{M}-\mathrm{H}]^{-}$ions from carboxylic acids and has been studied extensively in atmospheric pressure chemical ionization sources (APCI) (Horning et al., 1977; Kückelmann et al., 2000; McEwen and Larsen, 2009).

The CI-IMS-TOF was deployed for a 7-week period during the SOAS field campaign at the Centreville, AL, USA supersite (CTR). Data were acquired at 5 min time resolution for the duration of the campaign. This $5 \mathrm{~min}$ time resolution was chosen due to low ambient signals. Time resolutions as low as a data point every $5 \mathrm{~s}$ were utilized in laboratory experiments in which generated analyte concentrations were higher. The drift and desolvation tubes were maintained at $60^{\circ} \mathrm{C}$ for the first half of SOAS and $150^{\circ} \mathrm{C}$ for the second half. Higher temperatures reduced clustering between analyte and water molecules (due to high ambient humidity levels) in the drift tube but decreased ion mobility resolution. Dry $\mathrm{N}_{2}$ gas counterflow can also be used to limit such clustering in the drift tube, but it was not employed during the campaign. The pressure in the drift tube typically fluctuated from 5 to 20 mbar above atmospheric pressure. Variations in pressure and temperature are corrected for during postprocessing using Eq. (1).

Laboratory experiments were also conducted to investigate the gas-phase chemistry of biogenic VOC oxidation with the CI-IMS-TOF. In these experiments, a counterflow of $\mathrm{N}_{2}$ was utilized with the drift tube maintained at a temperature of $100{ }^{\circ} \mathrm{C}$. Oxidation products of isoprene, $\alpha$-pinene, and limonene were generated by reaction with ozone $\left(\mathrm{O}_{3}\right)$ and/or hydroxyl $(\mathrm{OH})$ radicals inside a potential aerosol mass (PAM) oxidation flow reactor (Kang et al., 2007; Lambe et al., 2011) via the reaction $\mathrm{O}_{3}+h v \rightarrow \mathrm{O}_{2}+\mathrm{O}\left({ }^{1} \mathrm{D}\right)$ followed by the reaction $\mathrm{O}\left({ }^{1} \mathrm{D}\right)+\mathrm{H}_{2} \mathrm{O} \rightarrow 2 \mathrm{OH}$. $\mathrm{O}_{3}$ was generated by irradiating $\mathrm{O}_{2}$ with a mercury lamp $(\lambda=185 \mathrm{~nm})$ outside the PAM reactor.

\section{Offline IMS-MS measurements of ambient SOA}

\subsection{ESI-IMS-MS of ambient aerosol filter}

Figure 2 shows an example of a 2-D ESI-IMS-MS spectrum measured from a SOAS (LRK site, 16 June 2013) aerosol filter sample. In the 2-D image, IMS drift time is shown on the vertical axis and $m / z$ is displayed on the horizontal axis. Because we have not corrected the data for transit times outside of the IMS drift cell, we report drift times as "apparent drift times". The panel above the 2-D plot shows the mass spectrum that results from summing across all displayed IMS drift times. The ion mobility spectrum on the right of Fig. 2 is the sum ion mobility spectrum for all displayed high-resolution $m / z$ values $(m / z$ 50-600). Hundreds of individual features are visible as dark-colored points in the 2-D plot. Each feature corresponds to an individual molecule that was ionized, separated, and detected with ESI-IMSMS; the horizontal position of each feature corresponds to a high-resolution $\mathrm{m} / \mathrm{z}$ from which the elemental composition is derived. The vertical position of each feature is the IMS drift time, which is used to obtain its reduced mobility and thus information about its molecular structure. Since compounds with different structures will generally have different drift times, the mobility separation helps deconvolve complex mass spectral features (including isomers and isobars) that are otherwise unresolvable by TOF MS alone. Stark et al. (2015) have shown that a high-resolution TOF with a MS resolution $m / \mathrm{d} m_{50}$ of 4000 cannot unambiguously resolve peaks beyond $\mathrm{m} / z .100$ due to the multitude of species present. The addition of an extra drift time dimension increases effective resolving power of the spectrometer while also providing valuable structural information about the analyte. In addition to individual features, mass-mobility correlations or trend lines in the 2-D spectrum can be used to elucidate bulk chemical composition in complex samples (Kanu et al., 2008). For example, a distinct series of highintensity peaks in the top right of the Fig. 22 -D plot that begins at $m / z 458$ and DT $\sim 46 \mathrm{~ms}$ and ends at $\mathrm{m} / z 590$ and DT $\sim 55 \mathrm{~ms}$. Trend lines of relevance to atmospheric chemistry will be discussed in detail in Sect. 4.2.

\subsection{Separation of unresolved WSOC and isomeric species}

Previous LC/MS analyses of the filter material collected from the LRK site shown in Fig. 2 indicated the presence of WSOC species that could not be chromatographically resolved using LC due to solvent and column constraints (Budisulistiorini et al., 2015). For example, Figure 3a shows that during LC analysis, $m / z 215$ (trihydroxymethylbutylsulfate; Hettiyadura et al., 2015) coelutes with $m / z 199$ (sulfate ester of 2-methylglyceric acid; Lin et al., 2013) and other WSOC species at $m / z 183$ (sulfate ester of 3,4-dihydroxybutane-2one; Riva et al., 2015), 155 (glycolic acid sulfate; Galloway 

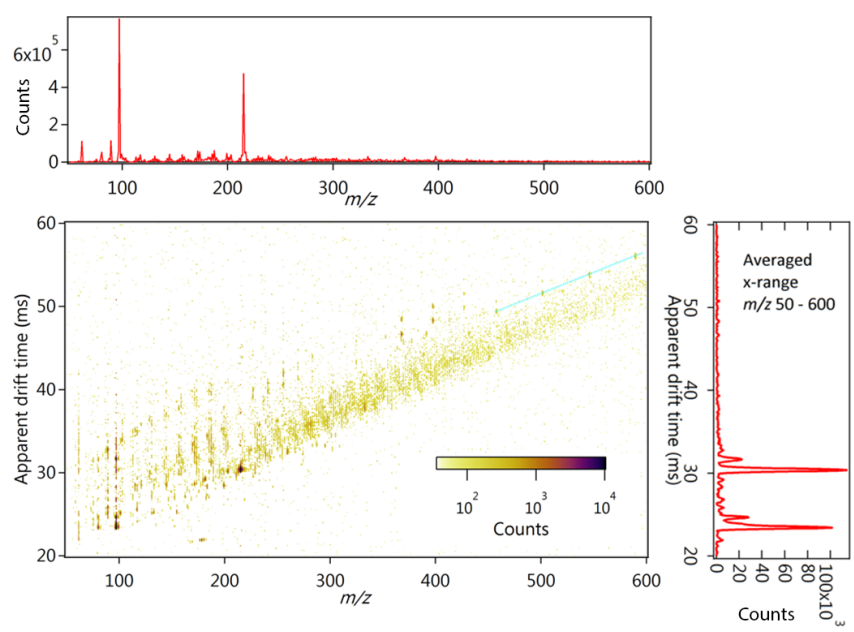

Figure 2. A typical representation of IMS-MS data in 2-D format for a SOAS filter sample (LRK site, 16 June 2013) analyzed via ESI-IMS-MS. The 2-D graph plots drift time vs. mass-to-charge $(\mathrm{m} / \mathrm{z})$ ratio. The top mass spectrum is the total mass spectrum for all displayed drift times $(20-60 \mathrm{~ms})$. The plot on the right is a total ion mobility spectrum for the entire displayed $\mathrm{m} / \mathrm{z}$ range (50-600). The light-blue line points out an example mass mobility correlation or trend line.

et al., 2009; Olson et al., 2011), and 133 (malic acid). On the other hand, as shown in Fig. 3b, some of these WSOC ions can be distinguished from each other by their ion mobility drift times: $m / z 215$ has a drift time that is clearly larger than the others, $m / z 199$ and 183 have intermediate drift times, and $m / z 155$ and 133 have the lowest drift times. The drift times of $m / z 155$ and $m / z 133$ differ from each other slightly. Further ion mobility separation of $m / z 199$ and $m / z 183$, however, appears to be limited by similarity in their CCS (collisional cross section).

In Fig. 3a, the dominant signal is due to $m / z 215$, a particle-phase organosulfate formed from isoprene oxidation under low-NO conditions (Surratt et al., 2010; Lin et al., 2012). Figure $S 1$ in the Supplement provides a mechanism for this process. Isoprene $\left(\mathrm{C}_{5} \mathrm{H}_{8}\right)$, the largest nonmethane hydrocarbon emission (Guenther et al., 1995) can form organosulfate aerosol in the presence of acidified sulfate aerosol under low-NO conditions (Edney et al., 2005; Gómez-González et al., 2008; Kroll et al., 2006; Surratt et al., 2008, 2010). Isoprene forms several epoxydiol isomers (collectively IEPOX) via $\mathrm{OH}$ radical-initiated oxidation of hydroxyhydroperoxide (ISOPOOH) intermediates (Crutzen et al., 2000; Paulot et al., 2009). IEPOX can be taken up by acidic aerosol at relatively short timescales (Gaston et al., 2014; Riedel et al., 2015) and reacts in the particle phase to form organosulfates. Several previous publications (GómezGonzález et al., 2008; Hettiyadura et al., 2015; Stone et al., 2012; Surratt et al., 2007, 2008, 2010) specifically identified a hydroxy sulfate ester (HSE; $\mathrm{C}_{5} \mathrm{H}_{11} \mathrm{O}_{7} \mathrm{~S}^{-}, 215.02 \mathrm{Da}$ ) as a large component of ambient and laboratory filter samples. Its (a)

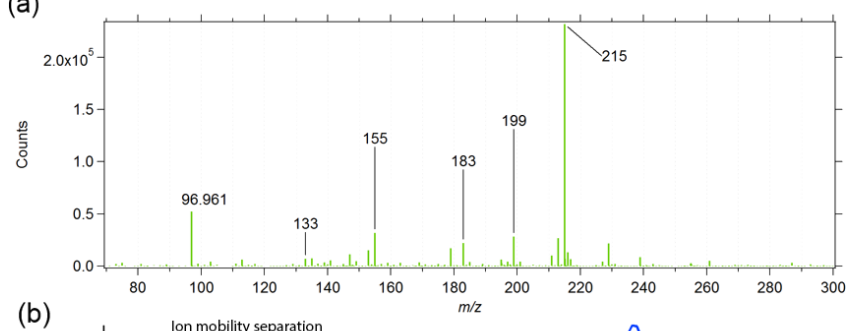

(b)

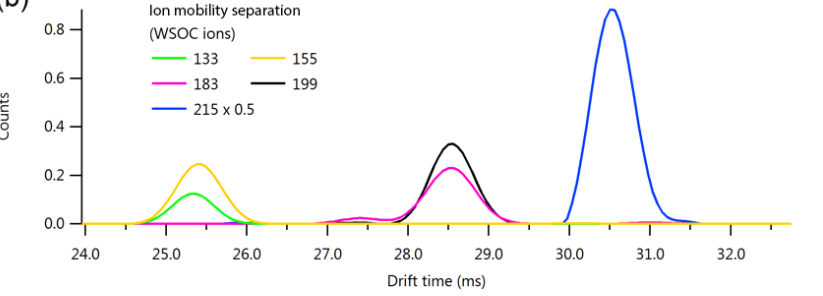

Figure 3. (a) An ESI-LC-MS filter mass spectrum (MS) extracted from the liquid chromatogram peak corresponding to the watersoluble organosulfate signal at $m / z 215$. The filter was taken during the SOAS campaign at the LRK site on 12 June 2013. LC is unable to resolve all of the compounds shown in the chromatogram. The ion mobility spectra for the MS peaks highlighted in (a) are shown in (b). The IM spectra were extracted from separate mass spectra and then placed together in the graph above for clarity. The watersoluble organic compounds are resolved by the IMS-TOF. The intensity for the ion mobility peak at $m / z 215$ has been scaled by a factor of 0.5 for visibility, as indicated in the legend.

molecular structure, however, has up to eight possible isomers (Hettiyadura et al., 2015), three of which are thought to be the major ones (Fig. S2) that depend on the IEPOX isomer from which it is derived. It is not well established which isomers predominate in atmospheric aerosol.

To investigate whether IMS-MS can be utilized to distinguish between the different HSE isomers, we analyzed laboratory samples of organosulfate aerosol generated from the reactive uptake of different IEPOX isomers along with one ambient filter from the LRK site (16 June 2013). A reference standard, sodium dodecyl sulfate (SDS; $\mathrm{NaC}_{12} \mathrm{H}_{25} \mathrm{SO}_{4}$; $288.372 \mathrm{~g} \mathrm{~mol}^{-1}$ ) was added to each filter analysis to correct any changes in drift times between experiments. Structures of the different HSE products and their IEPOX precursors can be found in Fig. S2.

The IMS spectra obtained from the laboratory HSE species are shown in Fig. 4, along with assigned structures. Three main isomers characterized by distinct drift times are observed as expected based on the mechanisms shown in Fig. S2. The laboratory-standard HSEs derived from cis- $\beta$ IEPOX and trans- $\beta$ IEPOX both show isomers at drift times 41.75 and $41.95 \mathrm{~ms}$, but the relative ratios of the isomers at these drift times are different for the two precursors. The third peak in the cis- $\beta$ IEPOX IMS spectrum at $41.6 \mathrm{~ms}$ does not appear to be related to HSEs. It is linked instead to another ion that is isobaric with HSE and is observed as a shoulder on the HSE peak in the high-resolution mass spectrum. 


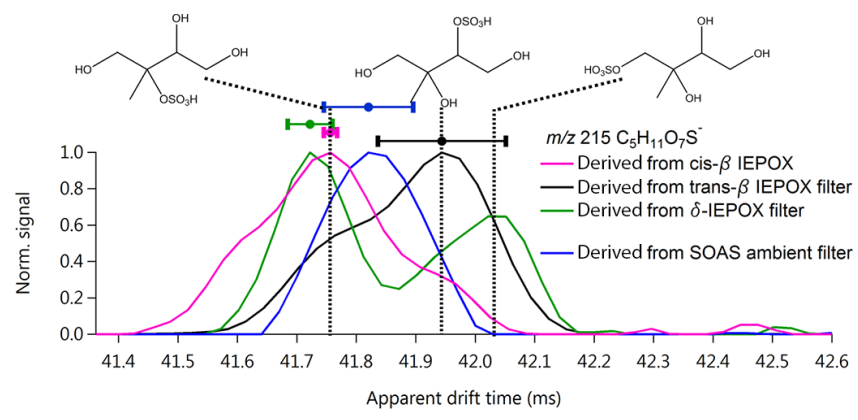

Figure 4. Ion mobility spectra of $\mathrm{HSE}\left(\mathrm{C}_{5} \mathrm{H}_{11} \mathrm{O}_{7} \mathrm{~S}^{-}\right)$in four different aerosol filter samples. Dashed vertical lines indicate the three different IMS peaks/isomers observed in different combinations in each sample. All spectra have been normalized to facilitate qualitative comparison. The bars on the top denote the uncertainty in the drift time dimension for each peak and were determined from the standard error of the mean of a mobility calibration compound from its average drift time.

The reactive uptake of $\delta$-IEPOX also yields two trihydroxybutylsulfate (also hydroxy sulfate ester, or HSE) isomers as expected. One isomer that is observed at $41.75 \mathrm{~ms}$ is identical to that produced from cis- $\beta$ IEPOX while the other is observed at a drift time of $42.03 \mathrm{~ms}$.

The HSE species in the LRK ambient sample produces one broad ion mobility peak at a drift time of $41.82 \mathrm{~ms}$. This $41.82 \mathrm{~ms}$ peak lies between the drift times observed for HSE isomers 1 and 3 . The HSE isomer 1 can be produced from both $\beta$-IEPOX and $\delta$-IEPOX, but the absence of the HSE isomer 2 , which is also a product of $\delta$-IEPOX, suggests that $\delta$-IEPOX does not contribute significantly to the observed ambient HSE. These observations are consistent with recent results which found that $\delta$-IEPOX is only produced with a $3 \%$ yield (Bates et al., 2014). The measured IMS drift time of ambient HSE lies between the two different IMS drift times measured for HSE produced from chamber experiments with cis- $\beta$ and trans- $\beta$ IEPOX products. This suggests that both cis- $\beta$ and trans- $\beta$ IEPOX contribute to the observed ambient HSE at LRK. This is consistent with recent ab initio calculations in the literature (St. Clair et al., 2015) that have also concluded that 1,2-ISOPOOH (the atmospherically dominant isomer; Rivera-Rios et al., 2014) has a $58 \%$ reaction pathway preference for cis- $\beta$ IEPOX and an $42 \%$ preference for trans- $\beta$ IEPOX, although the same work showed an experimental preference for trans- $\beta$ IEPOX.

The ambient and laboratory filter results shown in Fig. 4 were analyzed without any preseparation of the inorganic sulfate seeds from the organic aerosol species. Although the capability to separate the HSE isomers was demonstrated, resolution was likely reduced due to clustering in the drift tube between HSE ions and neutral sulfuric acid molecules formed from the acidic seed. The data in Fig. 4 were obtained at a drift tube pressure that was slightly higher than ambient (1400 mbar) to improve the ion mobility resolution.

\subsection{Molecular information from IMS-CID-MS}

In Sect. 3.2, isomer identification is achieved by direct measurements of the ion mobilities of laboratory standards. Molecular-level information can also be achieved by utilizing the IMS-MS technique with CID. Figure 5a and b show CID analysis of a synthesized standard of the 2-methylglyceric acid organosulfate derivative $\left(\mathrm{C}_{4} \mathrm{H}_{7} \mathrm{O}_{7} \mathrm{~S}^{-}\right.$; exact calculated mass: $198.99 \mathrm{~g} \mathrm{~mol}^{-1}$ ). This compound produces a CID pattern that contains two distinct peaks that appear at the same drift time as the precursor ion; identical drift times for precursor and fragment ions are expected as the fragmentation takes place after IMS separation (IMS-CID-MS). Taken together, the ions at $m / z 199$ (which corresponds to the 2methylglyceric acid organosulfate derivate), $m / z 119$ (neutral loss of $\mathrm{SO}_{3}$ ), and $m / z 97$ (which corresponds to $\mathrm{HSO}_{4}^{-}$) confirm the chemical structure of the standard and the fact that it contains sulfate. The peaks mentioned above in IMSCID-MS spectrum corresponding to the precursor drift time (Fig. 5b) match the MS/MS spectrum published in GómezGonzález et al. (2008), demonstrating that IMS-CID-MS fragmentation patterns are consistent with traditional tandem mass spectrometry measurements.

Figure 5c shows the 2-D plot for an aerosol filter sample derived from the reactive uptake of authentic IEPOX onto acidified sulfate aerosol under dark chamber conditions and analyzed using ESI-IMS-CID-MS. The plot shows a series of signals that correspond to elemental formulas of deprotonated $\left([\mathrm{M}-\mathrm{H}]^{-}\right)$and dehydrated $\left(\left[\mathrm{M}-\mathrm{H}_{2} \mathrm{O}\right]^{-}\right)$hydroxyl sulfate ester dimers and trimers from condensed-phase accretion reactions. These oligomers are readily identified in the 2-D IMS-MS spectrum because they lie along the same diagonal trend line (See Sect. 4.2 below for more discussion of trend lines). Figure $5 \mathrm{c}$ was achieved with a CID potential of 28 volts (fragmentation occurs in the region of the second quadrupole). The fragmentation of the dimer at $m / z 333$ results in the loss of neutral $\mathrm{C}_{5}$ dihydroxycarbonyl, which leaves the original trihydroxybutylsulfate at $\mathrm{m} / z 215$ as an observable fragment ion. This pathway was previously established in the literature (Surratt et al., 2008). The CID fragmentation pattern of $\mathrm{m} / z 215$ is also consistent with previous MS/MS analysis (Gómez-González et al., 2008), which shows that $\mathrm{HSE}$ fragments into $\mathrm{HSO}_{4}^{-}$, detected at $m / z 97$, and an undetectable neutral molecule. As in the case of Fig. 5a and b, the presence of the $\mathrm{HSO}_{4}^{-}$fragment in the CID spectra of both the dimer and the monomer is a clear indication that they both contain sulfate moieties.

\section{Online IMS-MS of biogenic VOC (BVOC) oxidation products in gas phase}

One goal of the SOAS 2013 campaign was to understand the reactions that lead to the oxidation of BVOC. During SOAS the $\mathrm{NO}_{3}^{-}$IMS-TOF was deployed at the Centreville, 

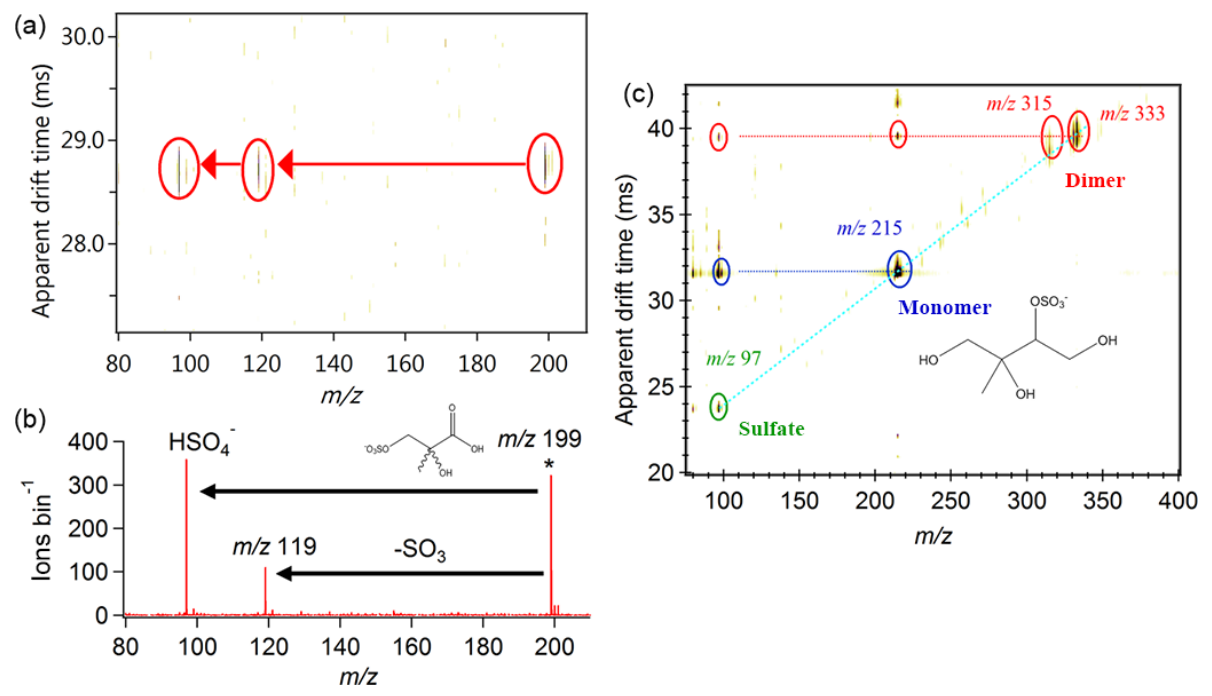

Figure 5. (a) 2-D IMS-CID-MS plot for a synthesized chemical standard of 2-methylglyceric acid organosulfate derivative and (b) its characteristic fragment ion mass spectrum. The CID mass spectra match previously published MS/MS measurements (Gómez-González et al., 2008). (c) 2-D IMS-CID-MS plot of a chamber-generated aerosol filter sample. Organic aerosol was generated in the UNC smog chamber from the reactive uptake of authentic IEPOX onto acidic sulfate aerosol under dark conditions (Lin et al., 2012, 2014). Deprotonated and dehydrated organosulfate dimers and monomers are observed. The organosulfate dimer $(\mathrm{m} / \mathrm{z} 333)$ is observed decaying into the organosulfate monomer $(m / z 215)$ and both are observed further decomposing into $\mathrm{HSO}_{4}^{-}$, which also matches previous literature results (Surratt et al., 2008).

Alabama field site, which is influenced by isoprene and terpene BVOCs. Previous studies have shown that $\mathrm{NO}_{3}^{-} \mathrm{CI}$ can be used to efficiently and selectively detect highly oxidized molecules with multiple oxygenated functional groups that are photochemically produced from isoprene and terpenes in the gas phase (Ehn et al., 2012; Hyttinen et al., 2015; Jokinen et al., 2012). In ambient environments these highly oxidized gas-phase species are present at low ambient concentrations (ppt levels), but they can condense onto particles and be a significant contribution to particle growth and particle composition (Ehn et al., 2014). The IMS-MS measurements described here provide the opportunity to detect the isomeric and isobaric variants of these species that cannot be resolved with the $\mathrm{NO}_{3}^{-}$CIMS techniques measurements alone. This information is important for developing a better understanding of the reaction pathways that form these highly oxidized species and for characterizing their partitioning behavior between the gas and particle phases. To our knowledge, this is the first deployment of an IMS-MS instrument for field measurements of gas-phase species.

During SOAS 2013, the $\mathrm{NO}_{3}^{-}$IMS-MS data were collected at high time resolution with a 2-D IMS-MS spectrum every $5 \mathrm{~min}$. Figure 6a shows a 2-D NO 3 -IMS-MS plot obtained by averaging over one $8 \mathrm{~h}$ period of SOAS CTR field data. The grey crosses in the background of the plot are peaks observed in the ambient measurements. On top of the ambient data are markers corresponding to BVOC oxidation products generated from ozonolysis and low-NO photooxidation of specific BVOC precursors (isoprene, limonene, and $\alpha$ - pinene) in the laboratory PAM oxidation flow reactor. Highresolution peak fitting of the IMS-TOF mass spectra (Cubison and Jimenez, 2015) is used to assign molecular formulas to the ion signals obtained for the data in Fig. 6a. The reduced mobility of each ion in the lab and field measurements shown in Fig. 6a was calculated from the measured drift times and pressure using Eq. (1).

The molecular formulas obtained from the field and laboratory data are consistent with previously published $\mathrm{NO}_{3}$ CIMS gas-phase BVOC product spectra (Ehn et al., 2012; Jokinen et al., 2015; Krechmer et al., 2015). Many of the elemental compositions detected in the mass spectral range of $m / z, 180-250$ correspond to previously identified products of isoprene oxidation (Jokinen et al., 2015; Krechmer et al., 2015) and the majority of the ion signals detected between $m / z 300$ and 425 match the formulas of $\alpha$-pinene and limonene monomeric products that were previously identified as highly oxidized multifunctional organic compounds (HOMs) (Ehn et al., 2014; Jokinen et al., 2015). Also highlighted are the $\alpha$-pinene HOMs peroxy radicals (Mentel et al., 2015), which will be discussed in the next section. Ion signals detected between $m / z 425$ and 600 in Fig. 6a correspond to $\alpha$-pinene and limonene HOMs dimers that are observed in the laboratory experiments (Ehn et al., 2012; Jokinen et al., 2015). Although some HOMs dimer signals were observed, most of the HOMs dimer signals did not have sufficient $S / N$ during the ambient measurements, likely due to inlet losses and poor ion transmission. Two isomers of a key high-NO $\alpha$-pinene ozonolysis product $\left(\mathrm{C}_{10} \mathrm{H}_{15} \mathrm{NO}_{8}\right.$ 
(a)

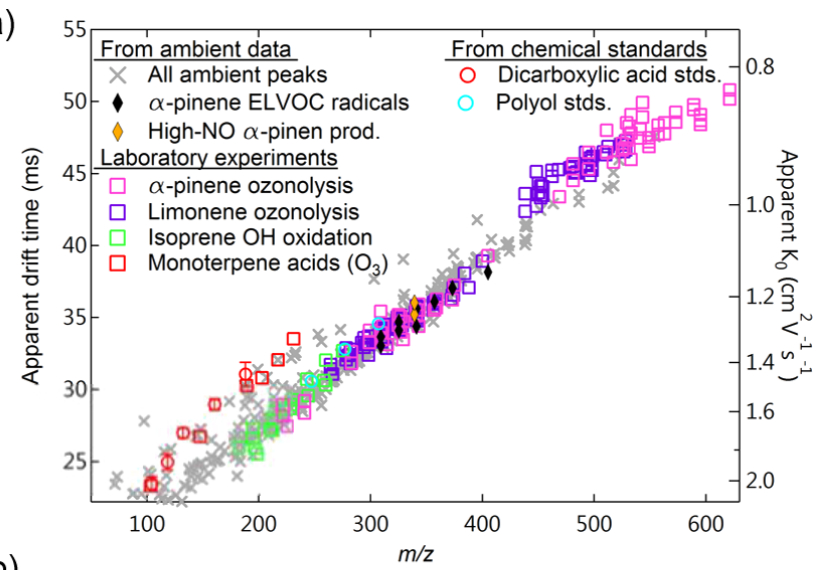

(b)

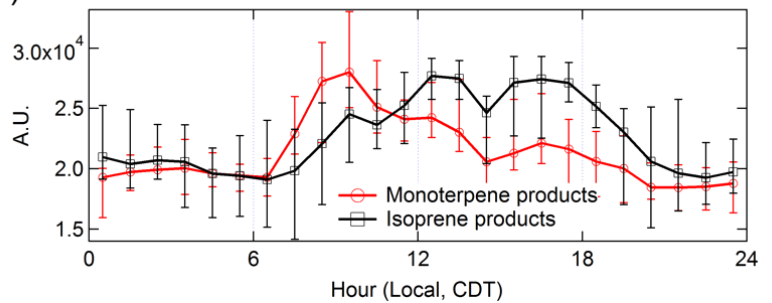

Figure 6. (a) 2-D plot showing an $8 \mathrm{~h}$ average of $\mathrm{SOAS} \mathrm{NO}_{3}$-IMSMS spectra acquired at the CTR supersite. Data from laboratory measurements of chemical standards and BVOC oxidation studies are plotted on top of the ambient data. Monoterpene and isoprene products were generated in a PAM oxidation flow reactor by oxidation with $\mathrm{O}_{3}$ and $\mathrm{OH}$ and analytical standards were sublimated before ionization. (b) Diurnal cycles for the sum of the monoterpene and isoprene peaks highlighted in (a) over a 2-week period during the SOAS campaign. Dicarboxylic acid standards comprised $\mathrm{C}_{3}, \mathrm{C}_{4}, \mathrm{C}_{5}, \mathrm{C}_{7}$, and $\mathrm{C}_{9}$ dicarboxylic acids and polyol standards included threitol, xylitol, and mannitol.

clustered with $\mathrm{NO}_{3}^{-}, m / z$ 339) are included in Fig. 6a. This product was previously identified as a high-NO nitratecontaining oxidation product of $\alpha$-pinene in ambient $\mathrm{NO}_{3}^{-}$ (Kulmala et al., 2013) and $\mathrm{I}^{-}$-CIMS measurements (Lee et al., 2016). Other organic nitrate gas-phase compounds were not observed with sufficient $S / N$ in the CI-IMS-TOF ambient data.

Ambient diurnal cycles of the summed mass spectral signals of the isoprene and monoterpene oxidation products are shown in Fig. 6b. The diurnal averages are derived over a 2 -week period in the middle of the SOAS campaign. The isoprene-attributed signal peaks in the late afternoon and declines rapidly at night. On the other hand, the monoterpene signal, which is obtained by summing over all ions identified as $\alpha$-pinene and limonene oxidation products in Fig. 6a, peaks in the early morning and declines throughout the day. Both are consistent with other published SOAS results (Krechmer et al., 2015).

The new information provided from the IMS-TOF is the reduced mobility of each ion, which, as shown in Fig. 6a, can be calculated from the measured drift times and pressure

using Eq. (1). The reduced mobilities measured for ambient ions lie in the same regions of the 2-D IMS-MS space as the laboratory products of the isoprene and terpene products. Comparisons between IMS measurements of laboratory and field IMS measurements for the same ion could provide a valuable means of identifying the precursors of the isobaric/isomeric species that are separated with the IMS. However, such detailed intercomparisons are precluded in this case by the fact that the two data sets were obtained under different operating conditions that cannot be accounted for with Eq. (1). In particular, the ambient data were collected without a nitrogen counterflow in the IMS drift tube and under conditions of high ambient humidity (mean temperature and relative humidity (RH) of ambient air were $25^{\circ} \mathrm{C}$ and $83 \%$; Hidy et al., 2014) while the laboratory data were collected with a nitrogen counterflow and negligible humidity $(\sim 15 \%)$. It is also important to note that the absolute values of the reported reduced mobilities for this study should be taken with caution since they were not explicitly calibrated with an IMS standard. Most accepted ion mobility standards (Fernández-Maestre et al., 2010), and many of the molecules studied in this work strongly cluster with the $\mathrm{NO}_{3}^{-}$reagent ion from the CI source or water, which were both present in large quantities in the drift tube, particularly during SOAS. As a result, the typical conditions used for mobility calibrations (ESI-IMS-MS) do not reproduce the drift tube conditions under which the ambient/PAM IMS-TOF measurements were made. Future studies should address the issue of validating ion mobility calibration compounds that work well with different CIMS ionization schemes.

Figure 6a depicts many examples of isomeric and isobaric compounds in the ambient and laboratory data that are separated in the ion mobility drift space and that would not have been separated in $m / z$ space with a medium-resolution ( $\sim 4000$ resolving power) TOF MS. A list of the BVOC HOM ions observed following BVOC oxidation in the PAM reactor is given in Table 1, along with the number of isomers observed for each HOM. Examples of the types of separations observed in the laboratory and ambient data are illustrated in Fig. 7 with three MS peaks. All three MS peaks (two from laboratory experiments and $\mathrm{m} / \mathrm{z} 339$ from ambient data) in Fig. 7 have been analyzed with multipeak high-resolution analysis (Stark et al., 2015). The peaks at $m / z 240$ and $310\left(\mathrm{C}_{5} \mathrm{H}_{6} \mathrm{O}_{7}, \mathrm{C}_{9} \mathrm{H}_{12} \mathrm{O}_{8}, \mathrm{C}_{10} \mathrm{H}_{16} \mathrm{O}_{7}\right.$ clustered with $\mathrm{NO}_{3}^{-}$) were previously identified as low-NO $\alpha$ pinene ozonolysis products (Ehn et al., 2012) and the peak at $m / z 339\left(\mathrm{C}_{10} \mathrm{H}_{15} \mathrm{NO}_{8}\right.$ clustered with $\left.\mathrm{NO}_{3}^{-}\right)$was previously identified as a high-NO nitrate-containing oxidation product of $\alpha$-pinene with I ${ }^{-}$(Lee et al., 2016) CIMS measurements. For $m / z 240\left(\mathrm{C}_{5} \mathrm{H}_{6} \mathrm{O}_{7}\right.$ clustered with $\left.\mathrm{NO}_{3}^{-}\right)$, the fact that the IMS drift time profile shows a single peak confirms the existence of only a single compound at this mass. The MS peak at $\mathrm{m} / \mathrm{z} 310$ is fit using two isobaric peaks corresponding to $\mathrm{NO}_{3}^{-}$clusters of $\mathrm{C}_{9} \mathrm{H}_{12} \mathrm{O}_{8}$ and $\mathrm{C}_{10} \mathrm{H}_{16} \mathrm{O}_{7}$. Two IMS peaks are observed for the unit mass MS peak, confirming 
Table 1. Elemental formulas, $m / z$ values, and the number of isomers measured with IMS-TOF. Data were extracted from $\mathrm{O}_{3}$ and/or $\mathrm{OH}$ oxidation of the BVOCs (isoprene, limonene, and $\alpha$-pinene) in the PAM reactor. Elemental formulas were previously identified in the literature: (1) Ehn et al. (2012), (2) Krechmer et al. (2015), (3) Jokinen et al. (2015). All compounds were detected as clusters with the nitrate ion $\left(\mathrm{NO}_{3}^{-}\right)$. Some compounds previously identified in the abovementioned literature were not observed in these laboratory experiments and are listed as having 0 isomers.

\begin{tabular}{|c|c|c|c|c|c|c|c|c|c|}
\hline Formula & $\begin{array}{l}\text { Ion } m / z \\
\text { clustered } \\
\text { with } \mathrm{NO}_{3}^{-}\end{array}$ & $\begin{array}{l}\text { Number of } \\
\text { isomers }\end{array}$ & Precursor & Ref. & Formula & $\begin{array}{l}\text { Ion } m / z \\
\text { clustered } \\
\text { with } \mathrm{NO}_{3}^{-}\end{array}$ & $\begin{array}{l}\text { Number of } \\
\text { isomers }\end{array}$ & Precursor & Ref. \\
\hline $\mathrm{C}_{7} \mathrm{H}_{10} \mathrm{O}_{4}$ & 220.05 & 1 & $\alpha$-pinene & 1 & $\mathrm{C}_{9} \mathrm{H}_{14} \mathrm{O}_{5}$ & 264.07 & 1 & limonene & 3 \\
\hline $\mathrm{C}_{5} \mathrm{H}_{6} \mathrm{O}_{6}$ & 224.00 & 1 & $\alpha$-pinene & 1 & $\mathrm{C}_{9} \mathrm{H}_{16} \mathrm{O}_{5}$ & 266.09 & 1 & limonene & 3 \\
\hline $\mathrm{C}_{5} \mathrm{H}_{6} \mathrm{O}_{7}$ & 240.00 & 1 & $\alpha$-pinene & 1 & $\mathrm{C}_{10} \mathrm{H}_{16} \mathrm{O}_{5}$ & 278.09 & 1 & limonene & 3 \\
\hline $\mathrm{C}_{7} \mathrm{H}_{8} \mathrm{O}_{8}$ & 282.01 & 1 & $\alpha$-pinene & 1 & $\mathrm{C}_{9} \mathrm{H}_{14} \mathrm{O}_{6}$ & 280.07 & 1 & limonene & 3 \\
\hline $\mathrm{C}_{8} \mathrm{H}_{12} \mathrm{O}_{7}$ & 282.05 & 1 & $\alpha$-pinene & 1 & $\mathrm{C}_{9} \mathrm{H}_{15} \mathrm{O}_{6}$ & 281.08 & 1 & limonene & 3 \\
\hline $\mathrm{C}_{8} \mathrm{H}_{12} \mathrm{O}_{8}$ & 298.04 & 1 & $\alpha$-pinene & 1 & $\mathrm{C}_{9} \mathrm{H}_{16} \mathrm{O}_{6}$ & 282.08 & 1 & limonene & 3 \\
\hline $\mathrm{C}_{10} \mathrm{H}_{14} \mathrm{O}_{7}$ & 308.06 & 1 & $\alpha$-pinene & 1 & $\mathrm{C}_{10} \mathrm{H}_{14} \mathrm{O}_{6}$ & 292.07 & 1 & limonene & 3 \\
\hline $\mathrm{C}_{9} \mathrm{H}_{12} \mathrm{O}_{8}$ & 310.04 & 1 & $\alpha$-pinene & 1 & $\mathrm{C}_{10} \mathrm{H}_{16} \mathrm{O}_{6}$ & 294.08 & 1 & limonene & 3 \\
\hline $\mathrm{C}_{10} \mathrm{H}_{16} \mathrm{O}_{7}$ & 310.08 & 1 & $\alpha$-pinene & 1 & $\mathrm{C}_{9} \mathrm{H}_{14} \mathrm{O}_{7}$ & 296.06 & 1 & limonene & 3 \\
\hline $\mathrm{C}_{8} \mathrm{H}_{12} \mathrm{O}_{9}$ & 314.04 & 1 & $\alpha$-pinene & 1 & $\mathrm{C}_{9} \mathrm{H}_{15} \mathrm{O}_{7}$ & 297.07 & 1 & limonene & 3 \\
\hline $\mathrm{C}_{10} \mathrm{H}_{14} \mathrm{O}_{8}$ & 324.06 & 1 & $\alpha$-pinene & 1 & $\mathrm{C}_{9} \mathrm{H}_{16} \mathrm{O}_{7}$ & 298.08 & 1 & limonene & 3 \\
\hline $\mathrm{C}_{10} \mathrm{H}_{16} \mathrm{O}_{8}$ & 326.04 & 1 & $\alpha$-pinene & 1 & $\mathrm{C}_{10} \mathrm{H}_{14} \mathrm{O}_{7}$ & 308.06 & 2 & limonene & 3 \\
\hline $\mathrm{C}_{9} \mathrm{H}_{12} \mathrm{O}_{9}$ & 326.07 & 1 & $\alpha$-pinene & 1 & $\mathrm{C}_{10} \mathrm{H}_{16} \mathrm{O}_{7}$ & 310.08 & 2 & limonene & 3 \\
\hline $\mathrm{C}_{9} \mathrm{H}_{14} \mathrm{O}_{9}$ & 328.05 & 1 & $\alpha$-pinene & 1 & $\mathrm{C}_{10} \mathrm{H}_{17} \mathrm{O}_{7}$ & 311.09 & 1 & limonene & 3 \\
\hline $\mathrm{C}_{10} \mathrm{H}_{14} \mathrm{O}_{9}$ & 340.05 & 2 & $\alpha$-pinene & 1 & $\mathrm{C}_{9} \mathrm{H}_{15} \mathrm{O}_{4}\left(\mathrm{HNO}_{3}\right)$ & 312.08 & 1 & limonene & 3 \\
\hline $\mathrm{C}_{9} \mathrm{H}_{12} \mathrm{O}_{10}$ & 342.03 & 2 & $\alpha$-pinene & 1 & $\mathrm{C}_{9} \mathrm{H}_{15} \mathrm{O}_{8}$ & 313.07 & 1 & limonene & 3 \\
\hline $\mathrm{C}_{10} \mathrm{H}_{16} \mathrm{O}_{9}$ & 342.07 & 1 & $\alpha$-pinene & 1 & $\mathrm{C}_{9} \mathrm{H}_{16} \mathrm{O}_{8}$ & 314.07 & 1 & limonene & 3 \\
\hline $\mathrm{C}_{10} \mathrm{H}_{14} \mathrm{O}_{10}$ & 356.05 & 2 & $\alpha$-pinene & 1 & $\mathrm{C}_{10} \mathrm{H}_{14} \mathrm{O}_{8}$ & 324.06 & 2 & limonene & 3 \\
\hline $\mathrm{C}_{10} \mathrm{H}_{16} \mathrm{O}_{10}$ & 358.03 & 2 & $\alpha$-pinene & 1 & $\mathrm{C}_{10} \mathrm{H}_{15} \mathrm{O}_{8}$ & 325.07 & 1 & limonene & 3 \\
\hline $\mathrm{C}_{9} \mathrm{H}_{12} \mathrm{O}_{11}$ & 358.06 & 1 & $\alpha$-pinene & 1 & $\mathrm{C}_{10} \mathrm{H}_{16} \mathrm{O}_{8}$ & 326.07 & 1 & limonene & 3 \\
\hline $\mathrm{C}_{10} \mathrm{H}_{14} \mathrm{O}_{11}$ & 372.04 & 1 & $\alpha$-pinene & 1 & $\mathrm{C}_{9} \mathrm{H}_{14} \mathrm{O}_{5}\left(\mathrm{HNO}_{3}\right)$ & 327.07 & 1 & limonene & 3 \\
\hline $\mathrm{C}_{10} \mathrm{H}_{16} \mathrm{O}_{11}$ & 374.02 & 1 & $\alpha$-pinene & 1 & $\mathrm{C}_{10} \mathrm{H}_{14} \mathrm{O}_{9}$ & 340.05 & 3 & limonene & 3 \\
\hline $\mathrm{C}_{10} \mathrm{H}_{14} \mathrm{O}_{13}$ & 404.03 & 1 & $\alpha$-pinene & 1 & $\mathrm{C}_{10} \mathrm{H}_{15} \mathrm{O}_{9}$ & 341.06 & 2 & limonene & 3 \\
\hline $\mathrm{C}_{17} \mathrm{H}_{26} \mathrm{O}_{11}$ & 468.14 & 1 & $\alpha$-pinene & 1 & $\mathrm{C}_{10} \mathrm{H}_{16} \mathrm{O}_{9}$ & 342.07 & 2 & limonene & 3 \\
\hline $\mathrm{C}_{18} \mathrm{H}_{26} \mathrm{O}_{11}$ & 480.14 & 3 & $\alpha$-pinene & 1 & $\mathrm{C}_{10} \mathrm{H}_{14} \mathrm{O}_{10}$ & 356.05 & 1 & limonene & 3 \\
\hline $\mathrm{C}_{19} \mathrm{H}_{28} \mathrm{O}_{11}$ & 494.15 & 2 & $\alpha$-pinene & 1 & $\mathrm{C}_{10} \mathrm{H}_{15} \mathrm{O}_{10}$ & 357.05 & 1 & limonene & 3 \\
\hline $\mathrm{C}_{20} \mathrm{H}_{32} \mathrm{O}_{11}$ & 510.18 & 2 & $\alpha$-pinene & 1 & $\mathrm{C}_{10} \mathrm{H}_{16} \mathrm{O}_{10}$ & 358.06 & 1 & limonene & 3 \\
\hline $\mathrm{C}_{17} \mathrm{H}_{26} \mathrm{O}_{14}$ & 516.12 & 1 & $\alpha$-pinene & 1 & $\mathrm{C}_{10} \mathrm{H}_{14} \mathrm{O}_{11}$ & 372.04 & 1 & limonene & 3 \\
\hline $\mathrm{C}_{20} \mathrm{H}_{30} \mathrm{O}_{12}$ & 524.16 & 2 & $\alpha$-pinene & 1 & $\mathrm{C}_{10} \mathrm{H}_{15} \mathrm{O}_{11}$ & 373.05 & 1 & limonene & 3 \\
\hline $\mathrm{C}_{19} \mathrm{H}_{28} \mathrm{O}_{13}$ & 526.14 & 2 & $\alpha$-pinene & 1 & $\mathrm{C}_{10} \mathrm{H}_{16} \mathrm{O}_{11}$ & 374.06 & 1 & limonene & 3 \\
\hline $\mathrm{C}_{18} \mathrm{H}_{26} \mathrm{O}_{14}$ & 528.12 & 2 & $\alpha$-pinene & 1 & $\mathrm{C}_{9} \mathrm{H}_{22} \mathrm{O}_{12}$ & 384.10 & 1 & limonene & 3 \\
\hline $\mathrm{C}_{18} \mathrm{H}_{28} \mathrm{O}_{14}$ & 530.14 & 2 & $\alpha$-pinene & 1 & $\mathrm{C}_{10} \mathrm{H}_{15} \mathrm{O}_{8}\left(\mathrm{HNO}_{3}\right)$ & 388.06 & 1 & limonene & 3 \\
\hline $\mathrm{C}_{17} \mathrm{H}_{26} \mathrm{O}_{15}$ & 532.12 & 2 & $\alpha$-pinene & 1 & $\mathrm{C}_{9} \mathrm{H}_{22} \mathrm{O}_{13}$ & 400.09 & 1 & limonene & 3 \\
\hline $\mathrm{C}_{20} \mathrm{H}_{30} \mathrm{O}_{13}$ & 540.16 & 2 & $\alpha$-pinene & 1 & $\mathrm{C}_{20} \mathrm{H}_{24} \mathrm{O}_{7}$ & 438.14 & 1 & limonene & 3 \\
\hline $\mathrm{C}_{20} \mathrm{H}_{32} \mathrm{O}_{13}$ & 542.17 & 2 & $\alpha$-pinene & 1 & $\mathrm{C}_{21} \mathrm{H}_{28} \mathrm{O}_{6}$ & 438.18 & 1 & limonene & 3 \\
\hline $\mathrm{C}_{17} \mathrm{H}_{26} \mathrm{O}_{16}$ & 548.11 & 2 & $\alpha$-pinene & 1 & $\mathrm{C}_{22} \mathrm{H}_{26} \mathrm{O}_{6}$ & 448.16 & 1 & limonene & 3 \\
\hline $\mathrm{C}_{20} \mathrm{H}_{30} \mathrm{O}_{14}$ & 556.15 & 2 & $\alpha$-pinene & 1 & $\mathrm{C}_{19} \mathrm{H}_{30} \mathrm{O}_{8}$ & 448.18 & 1 & limonene & 3 \\
\hline $\mathrm{C}_{18} \mathrm{H}_{28} \mathrm{O}_{16}$ & 562.13 & 2 & $\alpha$-pinene & 1 & $\mathrm{C}_{18} \mathrm{H}_{28} \mathrm{O}_{9}$ & 450.16 & 1 & limonene & 3 \\
\hline $\mathrm{C}_{20} \mathrm{H}_{30} \mathrm{O}_{15}$ & 572.15 & 2 & $\alpha$-pinene & 1 & $\mathrm{C}_{22} \mathrm{H}_{28} \mathrm{O}_{6}$ & 450.18 & 1 & limonene & 3 \\
\hline $\mathrm{C}_{20} \mathrm{H}_{32} \mathrm{O}_{15}$ & 574.00 & 1 & $\alpha$-pinene & 1 & $\mathrm{C}_{21} \mathrm{H}_{26} \mathrm{O}_{7}$ & 452.16 & 2 & limonene & 3 \\
\hline $\mathrm{C}_{20} \mathrm{H}_{30} \mathrm{O}_{16}$ & 588.14 & 2 & $\alpha$-pinene & 1 & $\mathrm{C}_{20} \mathrm{H}_{24} \mathrm{O}_{8}$ & 454.14 & 2 & limonene & 3 \\
\hline $\mathrm{C}_{18} \mathrm{H}_{28} \mathrm{O}_{18}$ & 594.12 & 3 & $\alpha$-pinene & 1 & $\mathrm{C}_{19} \mathrm{H}_{28} \mathrm{O}_{9}$ & 462.16 & 1 & limonene & 3 \\
\hline $\mathrm{C}_{20} \mathrm{H}_{30} \mathrm{O}_{18}$ & 620.13 & 2 & $\alpha$-pinene & 1 & $\mathrm{C}_{21} \mathrm{H}_{26} \mathrm{O}_{8}$ & 468.15 & 1 & limonene & 3 \\
\hline $\mathrm{C}_{2} \mathrm{H}_{4} \mathrm{O}_{4}$ & 154.00 & 0 & isoprene & 2 & $\mathrm{C}_{19} \mathrm{H}_{28} \mathrm{O}_{10}$ & 478.16 & 1 & limonene & 3 \\
\hline $\mathrm{C}_{4} \mathrm{H}_{8} \mathrm{O}_{4}$ & 182.03 & 1 & isoprene & 2 & $\mathrm{C}_{22} \mathrm{H}_{26} \mathrm{O}_{8}$ & 480.15 & 1 & limonene & 3 \\
\hline $\mathrm{C}_{5} \mathrm{H}_{8} \mathrm{O}_{4}$ & 194.03 & 2 & isoprene & 2 & $\mathrm{C}_{18} \mathrm{H}_{28} \mathrm{O}_{11}$ & 482.15 & 1 & limonene & 3 \\
\hline $\mathrm{C}_{4} \mathrm{H}_{6} \mathrm{O}_{5}$ & 196.01 & 1 & isoprene & 2 & $\mathrm{C}_{20} \mathrm{H}_{22} \mathrm{O}_{10}$ & 484.11 & 1 & limonene & 3 \\
\hline $\mathrm{C}_{4} \mathrm{H}_{8} \mathrm{O}_{5}$ & 198.03 & 1 & isoprene & 2 & $\mathrm{C}_{21} \mathrm{H}_{26} \mathrm{O}_{9}$ & 484.15 & 1 & limonene & 3 \\
\hline $\mathrm{C}_{5} \mathrm{H}_{12} \mathrm{O}_{4}$ & 198.06 & 1 & isoprene & 2 & $\mathrm{C}_{22} \mathrm{H}_{30} \mathrm{O}_{8}$ & 484.18 & 1 & limonene & 3 \\
\hline $\mathrm{C}_{5} \mathrm{H}_{8} \mathrm{O}_{5}$ & 210.03 & 1 & isoprene & 2 & $\mathrm{C}_{20} \mathrm{H}_{30} \mathrm{O}_{10}$ & 492.17 & 2 & limonene & 3 \\
\hline
\end{tabular}


Table 1. Continued.

\begin{tabular}{|c|c|c|c|c|c|c|c|c|c|}
\hline Formula & $\begin{array}{l}\text { Ion } m / z \\
\text { clustered } \\
\text { with } \mathrm{NO}_{3}^{-}\end{array}$ & $\begin{array}{l}\text { Number of } \\
\text { isomers }\end{array}$ & Precursor & Ref. & Formula & $\begin{array}{l}\text { Ion } m / z \\
\text { clustered } \\
\text { with } \mathrm{NO}_{3}^{-}\end{array}$ & $\begin{array}{l}\text { Number of } \\
\text { isomers }\end{array}$ & Precursor & Ref. \\
\hline $\mathrm{C}_{4} \mathrm{H}_{6} \mathrm{O}_{6}$ & 212.00 & 1 & isoprene & 2 & $\mathrm{C}_{19} \mathrm{H}_{28} \mathrm{O}_{11}$ & 494.15 & 2 & limonene & 3 \\
\hline $\mathrm{C}_{5} \mathrm{H}_{10} \mathrm{O}_{5}$ & 212.04 & 1 & isoprene & 2 & $\mathrm{C}_{18} \mathrm{H}_{26} \mathrm{O}_{12}$ & 496.13 & 2 & limonene & 3 \\
\hline $\mathrm{C}_{4} \mathrm{H}_{8} \mathrm{O}_{6}$ & 214.02 & 0 & isoprene & 2 & $\mathrm{C}_{19} \mathrm{H}_{30} \mathrm{O}_{11}$ & 496.17 & 1 & limonene & 3 \\
\hline $\mathrm{C}_{5} \mathrm{H}_{12} \mathrm{O}_{5}$ & 214.06 & 1 & isoprene & 2 & $\mathrm{C}_{18} \mathrm{H}_{28} \mathrm{O}_{12}$ & 498.15 & 1 & limonene & 3 \\
\hline $\mathrm{C}_{5} \mathrm{H}_{10} \mathrm{O}_{6}$ & 228.04 & 2 & isoprene & 2 & $\mathrm{C}_{22} \mathrm{H}_{28} \mathrm{O}_{9}$ & 498.16 & 1 & limonene & 3 \\
\hline $\mathrm{C}_{5} \mathrm{H}_{12} \mathrm{O}_{6}$ & 230.04 & 1 & isoprene & 2 & $\mathrm{C}_{20} \mathrm{H}_{36} \mathrm{O}_{10}$ & 498.22 & 2 & limonene & 3 \\
\hline $\mathrm{C}_{5} \mathrm{H}_{9} \mathrm{O}_{7}$ & 243.02 & 1 & isoprene & 3 & $\mathrm{C}_{20} \mathrm{H}_{30} \mathrm{O}_{11}$ & 508.17 & 2 & limonene & 3 \\
\hline $\mathrm{C}_{5} \mathrm{H}_{10} \mathrm{O}_{7}$ & 244.03 & 1 & isoprene & 3 & $\mathrm{C}_{20} \mathrm{H}_{32} \mathrm{O}_{11}$ & 510.18 & 1 & limonene & 3 \\
\hline $\mathrm{C}_{5} \mathrm{H}_{8} \mathrm{O}_{8}$ & 258.01 & 1 & isoprene & 3 & $\mathrm{C}_{19} \mathrm{H}_{30} \mathrm{O}_{1}$ & 512.16 & 2 & limonene & 3 \\
\hline $\mathrm{C}_{5} \mathrm{H}_{9} \mathrm{O}_{8}$ & 259.02 & 0 & isoprene & 3 & $\mathrm{C}_{20} \mathrm{H}_{30} \mathrm{O}_{12}$ & 524.16 & 3 & limonene & 3 \\
\hline $\mathrm{C}_{5} \mathrm{H}_{10} \mathrm{O}_{8}$ & 260.03 & 2 & isoprene & 3 & $\mathrm{C}_{19} \mathrm{H}_{28} \mathrm{O}_{13}$ & 526.14 & 2 & limonene & 3 \\
\hline \multirow[t]{2}{*}{$\mathrm{C}_{5} \mathrm{H}_{9} \mathrm{O}_{9}$} & 275.01 & 1 & isoprene & 3 & $\mathrm{C}_{22} \mathrm{H}_{26} \mathrm{O}_{11}$ & 528.14 & 2 & limonene & 3 \\
\hline & & & & & $\mathrm{C}_{19} \mathrm{H}_{30} \mathrm{O}_{13}$ & 528.16 & 2 & limonene & 3 \\
\hline
\end{tabular}

the two-constituent fit, but a key advantage of the IMS in this case is that it clearly helps identify the presence of two distinct species without the need for any multipeak fitting. Given systematic uncertainties in mass spectral peak fitting (Cubison and Jimenez, 2015), the ratio of the IMS peaks could give a more accurate intensity ratio. Finally, the MS peak at $m / z 339$ is fit entirely with one elemental formula $\left(\mathrm{NO}_{3}^{-}\right.$ cluster of $\mathrm{C}_{10} \mathrm{H}_{15} \mathrm{NO}_{8}$ ) but two IM peaks are observed. In this case, the IMS provides new information not available from MS alone, indicating that it is likely comprised of at least two structural isomers. Taken together, the examples in Fig. 7 illustrate the fact that separation along the IMS dimension can significantly increase the number of organic species that are measured and identified compared to MS alone.

As discussed earlier, the custom $\mathrm{NO}_{3}^{-} \mathrm{CI}$ source used in this study has a minor contribution from $\mathrm{O}_{2}^{-}$ion chemistry that primarily deprotonates acids, in addition to the dominant $\mathrm{NO}_{3}^{-}$ionization scheme. IMS-TOF measurements of commercially available dicarboxylic acids in the laboratory show a distinctly different trend line with higher drift times per $\mathrm{m} / \mathrm{z}$ than the isoprene/monoterpene trend lines. The BVOC oxidation products show signals that lie along this acid trend line and match the elemental formulas corresponding to many deprotonated acidic, monoterpene oxidation products that were identified in the aerosol phase in previous literature (Vogel et al., 2013). The acids were detected at uncharacteristically high drift times, but with $\mathrm{m} / \mathrm{z}$ values that corresponded to the $[\mathrm{M}-\mathrm{H}]^{-}$. The higher drift time measured for these small acid anions indicates that they traveled through the drift tube as a weakly bound cluster, likely with the neutral $\mathrm{HNO}_{3}$ molecules present in the drift tube, and were subsequently declustered in the instrument quadrupoles and detected in the TOF as the $[\mathrm{M}-\mathrm{H}]^{-}$ion. In fact, weak $\left[\mathrm{M}+\mathrm{NO}_{3}\right]^{-}$cluster signals are observed at the same high drift time for all of the acids in Fig. 6. This capability of us-

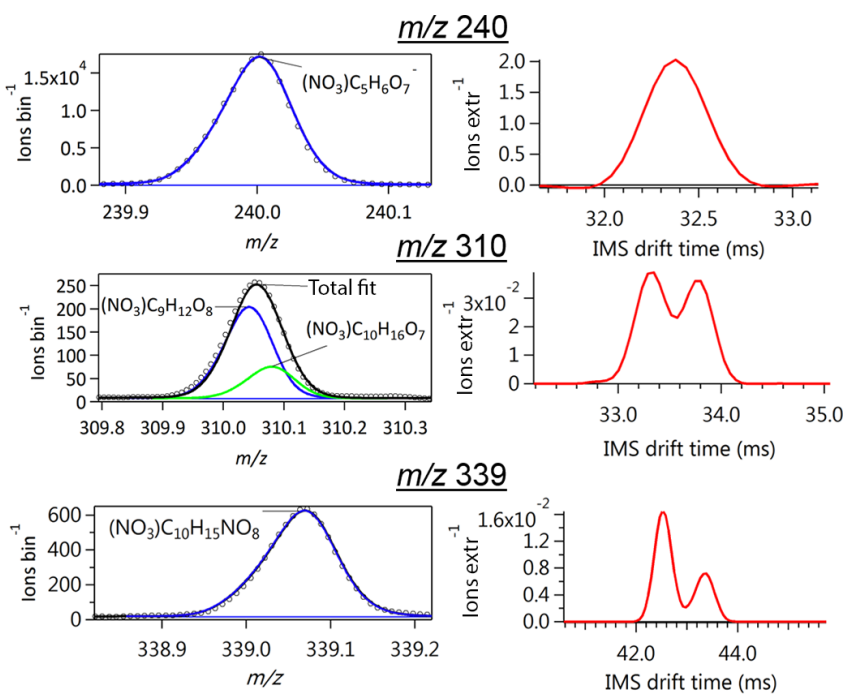

Figure 7. High-resolution peak fits for three gas-phase compounds along with the corresponding IM spectrum for each of the displayed mass-to-charge regions. The compounds selected include a single isomer $(\mathrm{m} / \mathrm{z} 240)$, isobaric compounds $(\mathrm{m} / \mathrm{z} 310)$, and isomeric compounds $(m / z, 339)$. The elemental formulas at $m / z 240$ $\left(\mathrm{C}_{5} \mathrm{H}_{6} \mathrm{O}_{7}\right.$ clustered with $\left.\mathrm{NO}_{3}^{-}\right)$and $m / z \quad 310\left(\mathrm{C}_{9} \mathrm{H}_{12} \mathrm{O}_{8}\right.$ and $\mathrm{C}_{10} \mathrm{H}_{16} \mathrm{O}_{7}$ clustered with $\mathrm{NO}_{3}^{-}$) were previously identified as $\alpha$ pinene ozonolysis products (Ehn et al., 2012). In this work they were extracted from spectra obtained during PAM flow reactor experiments of $\alpha$-pinene oxidation with $\mathrm{O}_{3}$ and $\mathrm{OH} . \mathrm{C}_{10} \mathrm{H}_{15} \mathrm{NO}_{8}$ $\left(m / z 339\right.$ clustered with $\mathrm{NO}_{3}^{-}$) was previously identified as a highNO $\alpha$-pinene oxidation product (Lee et al., 2016). The HR peak fits and IMS data shown for $m / z 339$ are extracted from ambient SOAS data.

ing the ion mobility drift time correlations to distinguish between clustered and deprotonated molecules can be particularly valuable for analyzing complex CIMS spectra obtained 

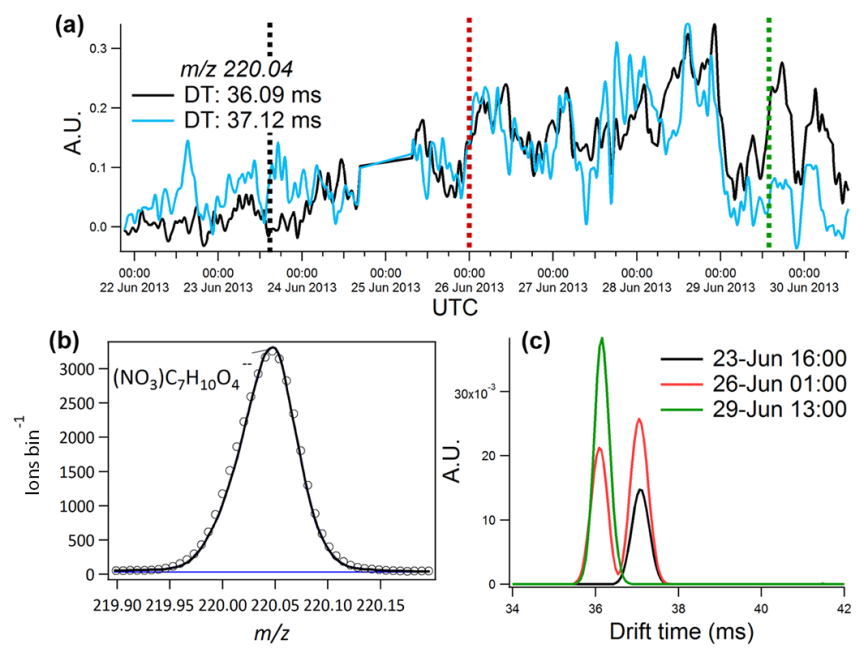

Figure 8. Panel (a) is a time series of two isomers observed in ion mobility space in the high-resolution (HR) mass spectral fit for the identified HOM (Ehn et al., 2012), $\mathrm{C}_{7} \mathrm{H}_{10} \mathrm{O}_{4}$ (detected as a cluster of $\mathrm{NO}_{3}^{-}$), produced from $\alpha$-pinene ozonolysis. The HR peak (b) for this mass is fit by a single $\left(\mathrm{NO}_{3}\right) \mathrm{C}_{7} \mathrm{H}_{10} \mathrm{O}_{4}^{-}$species. Panel (c) shows the ion mobility spectrum for $\mathrm{C}_{7} \mathrm{H}_{10} \mathrm{O}_{4}$ at three different points in the time series. IM spectra shown are obtained after postprocessing of the raw multiplexed ion mobility data.

with reagents, such as the acetate ion, which are known to participate in multiple ionization pathways (i.e., deprotonation and clustering) (Veres et al., 2008).

\subsection{Time-resolved measurement of gas-phase isomers}

As an additional example of high-resolution MS peak fitting, we provide the mass spectral peak at $m / z 220$ observed during SOAS (see Fig. 8). The high-resolution mass spectral peak was completely fit (Fig. 8b) with one elemental formula: $\mathrm{C}_{7} \mathrm{H}_{10} \mathrm{O}_{4}\left(m / z\right.$ 220.046), clustered with $\mathrm{NO}_{3}^{-}$. This elemental formula was identified in previous $\mathrm{NO}_{3}^{-}$-CIMS literature as a HOM produced from $\alpha$-pinene ozonolysis (Ehn et al., 2012). In Fig. 8c, we provide extracted IM spectra from the identified MS peak at three different points in the time series. The SOAS IMS data for this ion indicate the presence of two isomers. Two IMS peaks were detected with the same drift times at all four dates and times, but with different relative concentrations. The signals of these two isomers is plotted as a function of time for an 8-day period during the SOAS campaign in Fig. 8a. The fact that the time series of the compounds are similar suggests that they are both monoterpene oxidation products with sources and sinks that are similar in composition and magnitude. This is consistent with the laboratory measurements of $\alpha$-pinene oxidation products that also indicate the presence of isomeric constituents at $m / z 220$.

Organic molecules with the same elemental formula can have vastly different vapor pressures depending on the chem- ical functional groups they contain (Krechmer et al., 2015). Thompson et al. (2015) recently utilized the time-resolved IMS-TOF data from SOAS to confirm that the gas particle partitioning of pinic acid, which was measured during SOAS with the Filter Inlet for Gases and AEROsols high-resolution chemical ionization mass spectrometer (FIGAERO-CIMS; Lopez-Hilfiker et al., 2014) technique, was affected by interference from isomeric species. The IMS-TOF detected two different mobility peaks at the ion corresponding to pinic acid $\left(\mathrm{C}_{9} \mathrm{H}_{10} \mathrm{O}_{4}^{-}\right)$with very different relative time trends and concentrations during day and night. The IMS-TOF observations were in agreement with other evidence, such as thermograms, which also suggested the presence of additional isomeric or isobaric compounds with different vapor pressures from pinic acid.

\subsection{IMS-MS trend lines of $\alpha$-pinene HOMs}

Consistent correlations between mass and mobility are visible in 2-D plots of complex samples such as Fig. 6a. These correlations, known as "trend lines", describe the increase in collision cross section or decrease in mobility resulting from increasing functionalization of the molecule. As a result, they can be used to resolve structurally similar (similar size/shape) compounds that are otherwise unresolved in a standard the mass spectrum. Previously, trend lines have been used to separate classes of structures as diverse as large biomolecules (Ruotolo et al., 2008), metabolites (Dwivedi et al., 2008; Kaplan et al., 2010; Paglia et al., 2014), lipids (Groessl et al., 2015), and petroleum constituents (Fernandez-Lima et al., 2009).

Figure 9 shows an example of trend lines observed in the ambient SOAS 2-D NO $\mathrm{NO}_{3}^{-} \mathrm{IMS}-\mathrm{MS}$ spectra of $\alpha$-pinene HOMs radicals and neutral molecules. Mentel et al. (2015) have proposed that stable $\alpha$-pinene HOMs molecules are formed from $\alpha$-pinene peroxy radicals by three possible termination steps: formation of a carbonyl group, formation of a hydroxy group, or formation of a hydroperoxy group. Peroxy radicals are key intermediates in the rapid chemical formation of monoterpene HOM (Ehn et al., 2014; Jokinen et al., 2014; Mentel et al., 2015; Rissanen et al., 2015). The peroxy radicals identified in this work have elemental formulas $\mathrm{C}_{10} \mathrm{H}_{15} \mathrm{O}_{x}$, where $x=7-10$. Some higher-oxygen radicals $\left(\mathrm{O}_{11}-\mathrm{O}_{15}\right)$ were detected in the high-resolution mass spectrum, but had too little signal to extract statistically significant IMS peaks. While only the most intense isomers are shown in Fig. 9, multiple isomers are observed for the radicals and the neutral products. The trend lines are drawn for reference between the most intense isomers of each class of species. Termination products for each of the identified peroxy radicals are shown in Fig. 9 with arrows denoting their peroxy radical precursors. The hydroxy and hydroperoxy termination products were not separated in the IM spectra, however. We suspect this may be due to less-than-ideal ambient operating conditions or because the two products have 


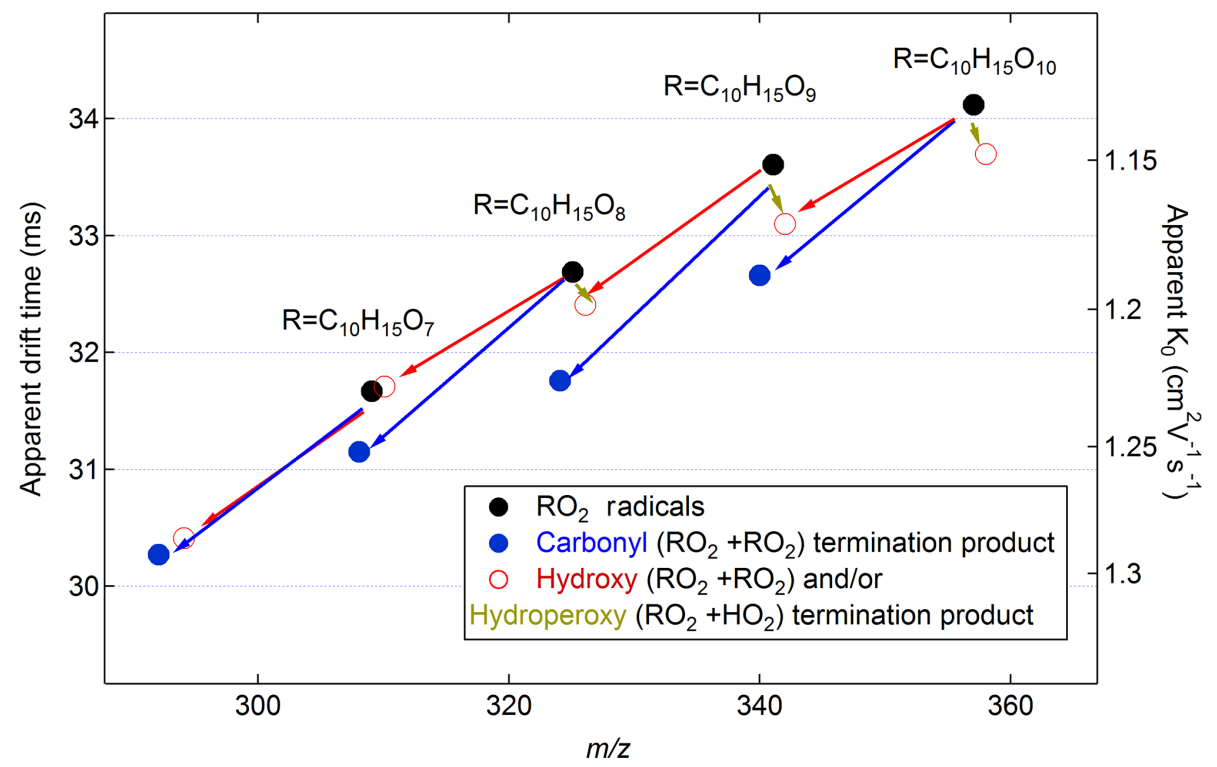

Figure 9. 2-D IMS-MS plot of select extracted masses from ambient SOAS NO 3 -IMS-MS data. Peroxy radicals $\left(\mathrm{C}_{10} \mathrm{H}_{15} \mathrm{O}_{x}\right.$, where $x=7-$ 10) are presented in 2-D space, along with their hydroperoxy (-OOH; $\left.\mathrm{C}_{10} \mathrm{H}_{16} \mathrm{O}_{x}\right)$, hydroxy $\left(-\mathrm{OH} ; \mathrm{C}_{10} \mathrm{H}_{16} \mathrm{O}_{x-1}\right)$, and carbonyl $(=\mathrm{O}$; $\mathrm{C}_{10} \mathrm{H}_{14} \mathrm{O}_{x-1}$ ) termination products, as identified in Mentel et al. (2015).

such similar CCS that they cannot be separated by this instrument. The most intense carbonyl termination products lie along a line with drift times that are consistently much lower than the radicals. The carbonyl products also lie along a different line to the - $\mathrm{OOH} /-\mathrm{OH}$ termination products. The elemental formulas for the hydroperoxy and hydroxy termination products overlap for neighboring radicals. For example, the $\mathrm{C}_{10} \mathrm{H}_{15} \mathrm{O}_{9}$ radical produces a hydroxy termination product with the same elemental formula $\left(\mathrm{C}_{10} \mathrm{H}_{16} \mathrm{O}_{8}\right)$ as the hydroperoxy termination product of $\mathrm{C}_{10} \mathrm{H}_{15} \mathrm{O}_{8}$ peroxy radical. This example illustrates the utility of the IMS-MS 2-D space for readily identifying groups of ions with similar functionalities and/or formation pathways within a complex mass spectrum.

In Fig. 9 the relative difference between the reduced mobility trend lines of the peroxy radicals and their hydroxyl/hydroperoxy and carbonyl products changes with degree of oxidation of the peroxy radical. This indicates changes in molecular structure of the peroxy radical and/or product structures with the degree of oxidation. In the $\alpha$ pinene system, several large changes in structure are expected to take place during oxidation due to the opening of the 4-membered ring as well as potential ring-closure reactions of peroxy radicals (Mentel et al., 2015; Rissanen et al., 2015). A detailed investigation of the structural information that can be extracted from these reduced mobility trends is beyond the scope of this manuscript. A forthcoming publication will focus on modeling molecular structures and collisional cross sections of these species.

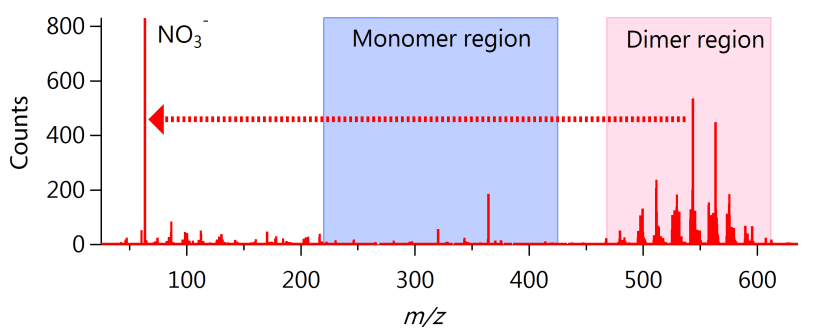

Figure 10. A 20V CID-MS of laboratory $\alpha$-pinene ozonolysis products averaged over the drift time region of the HOMs dimers (52$55 \mathrm{~ms}$ ) in the 2-D IMS-MS plot. Note that these data were acquired under different operating conditions than those in Fig. 6, leading to slightly different IMS drift times. The appearance of $\mathrm{NO}_{3}^{-}$-signal in the CID-MS results from fragmentation of the weak bond between $\mathrm{NO}_{3}^{-}$-and the $\alpha$-pinene HOMs dimer. The absence of monomer fragments in the CID-MS at this same voltage suggests that the monomer units within the dimers are bonded to each other more strongly (likely via covalent bonding). The large peak in the monomer region is a perfluoroheptanoic acid calibrant $(\mathrm{m} / \mathrm{z} 363)$.

\subsection{Investigation of bonding in $\alpha$-pinene HOM dimers}

Previous isotopic substitution $(H / D)$ experiments with $\mathrm{NO}_{3}^{-}$-CIMS (Rissanen et al., 2015) suggest that terpene HOM dimers are formed from covalent peroxy bonds between corresponding monomer units rather than weak intermolecular interactions. Here, we utilize the CID capability of the IMS to investigate the intermolecular bond strength in $\alpha$-pinene HOM dimers. IMS-CID-MS data were measured for CID voltages ranging from 0 to $20 \mathrm{~V}$. Since the 
HOM dimers are detected as $\mathrm{NO}_{3}^{-}$clusters, this CID experiment allowed for investigating the strength of the monomermonomer bond relative to the weakly bound dimer- $\mathrm{NO}_{3}^{-}$ bond. Figure 10 shows the average 1-D MS obtained for $20 \mathrm{~V}$ CID of the HOM dimer. The mass spectrum is averaged only over the drift time region that corresponds to the dimer signals in the 2-D IMS-CID-MS. A key result from Fig. 10 is that this CID MS only contains nitrate ion $\left(\mathrm{NO}_{3}^{-}\right)$ as the primary ionic fragmentation product. These ions result from fragmentation of the weakly bound cluster between the nitrate ion and the HOMs dimer. The absence of monomer signals in the CID-MS (they would have been found in the blue highlighted region) suggests that the monomer units in the dimer are not weakly bound clusters (i.e., they are bound more strongly, likely with a covalent bond). In the future, this technique can be calibrated for standard molecules and be used in a similar manner to characterize relative chemical bond strengths within gas-phase molecules and clusters.

\section{Conclusions}

We apply ion mobility spectrometry-mass spectrometry as a new technique for the analysis of atmospheric gas- and aerosol-phase species. Aerosol-phase data were taken from the offline ESI-IMS-MS analysis of filter samples. Using the filter samples, we demonstrated the capability of this technique to separate water soluble species and structural isomers of species such as trihydroxybutylsulfate which are not readily separated by other techniques such as LC/MS and GC/MS. The use of IMS-CID-MS to obtain spectra that are analogous to conventional MS/MS spectra is demonstrated. The fact that precursor and fragment ions are aligned in 2-D IMS-MS plots is used to obtain molecular structure information and to elucidate the monomer building blocks that make up higher molecular weight oligomers observed from experiments involving the reactive uptake of IEPOX onto wet acidic sulfate aerosol.

Online gas-phase IMS-MS data were acquired for laboratory ozonolysis and photooxidation experiments (using isoprene, $\alpha$-pinene, and limonene precursors) and from ambient measurements during the SOAS 2013 field campaign. The $\mathrm{NO}_{3}^{-}$CI source used for these measurements allowed for the detection of highly oxidized molecules in the gas phase. The HOMs produced from oxidation of $\alpha$-pinene, in particular, are investigated in more detail, and time-resolved separation of isomeric and isobaric species produced from this system is demonstrated. The 2-D IMS-MS space ( $m / z$ vs. IMS drift time) measured for $\alpha$-pinene HOMs is used to identify trend lines that separate out reactants and products from different chemical reaction pathways. Moreover, IMS-CID-MS spectra of the HOM dimers are used to confirm that the monomer units within these molecules are not weakly bound. Taken together, the gas and aerosol IMS-TOF data sets provide valuable chemical information that cannot be obtained from high- resolution mass spectrometry alone. More characterization of compound trend lines in 2-D space and theoretical collisional cross section (CCS) calculations is necessary to realize the IMS-TOF's potential as a tool for bulk analysis.

\section{The Supplement related to this article is available online at doi:10.5194/amt-9-3245-2016-supplement.}

Acknowledgements. We gratefully acknowledge funding from the US National Science Foundation (NSF) Atmospheric and Geospace Sciences (AGS) grants 1243354 and 1360834, NSF AGS-1537446 to ARI, NSF CHE-1404644, National Oceanic and Atmospheric Administration (NOAA) grants NA13OAR4310063 and NA13OAR4310064, Department of Energy (DOE) (BER/ASR program) DE-SC001110, DE-SC0011935 to BC, and Electric Power Research Institute (EPRI) 10004734. J.E.K. is grateful for fellowships from CIRES and EPA STAR (FP-91770901-0). EPA also funded the UNC group through grant \# 835404. The EPA has not reviewed this manuscript and thus no endorsement should be inferred. The authors are grateful to the SOAS organizers and fellow study participants. We would also like to thank Avram Gold and Zhenfa Zhang from UNC for their help with organic synthesis of IEPOX isomers and isoprene SOA constituents.

Edited by: P. Herckes

Reviewed by: two anonymous referees

\section{References}

Bates, K. H., Crounse, J. D., St Clair, J. M., Bennett, N. B., Nguyen, T. B., Seinfeld, J. H., Stoltz, B. M., and Wennberg, P. O.: Gas phase production and loss of isoprene epoxydiols., J. Phys. Chem. A, 118, 1237-1246, doi:10.1021/jp4107958, 2014.

Bradbury, N. E. and Nielsen, R. A.: Absolute Values of the Electron Mobility in Hydrogen, Phys. Rev., 49, 388-393, doi:10.1103/PhysRev.49.388, 1936.

Budisulistiorini, S. H., Li, X., Bairai, S. T., Renfro, J., Liu, Y., Liu, Y. J., McKinney, K. A., Martin, S. T., McNeill, V. F., Pye, H. O. T., Nenes, A., Neff, M. E., Stone, E. A., Mueller, S., Knote, C., Shaw, S. L., Zhang, Z., Gold, A., and Surratt, J. D.: Examining the effects of anthropogenic emissions on isoprenederived secondary organic aerosol formation during the 2013 Southern Oxidant and Aerosol Study (SOAS) at the Look Rock, Tennessee ground site, Atmos. Chem. Phys., 15, 8871-8888, doi:10.5194/acp-15-8871-2015, 2015.

Crutzen, P. J., Williams, J., Pöschl, U., Hoor, P., Fischer, H., Warneke, C., Holzinger, R., Hansel, A., Lindinger, W., Scheeren, B., and Lelieveld, J.: High spatial and temporal resolution measurements of primary organics and their oxidation products over the tropical forests of Surinam, Atmos. Environ., 34, 1161-1165, doi:10.1016/S1352-2310(99)00482-3, 2000.

Cubison, M. J. and Jimenez, J. L.: Statistical precision of the intensities retrieved from constrained fitting of overlapping peaks in high-resolution mass spectra, Atmos. Meas. Tech., 8, 23332345, doi:10.5194/amt-8-2333-2015, 2015. 
Dwivedi, P., Wu, P., Klopsch, S. J., Puzon, G. J., Xun, L., and Hill, H. H.: Metabolic profiling by ion mobility mass spectrometry (IMMS), Metabolomics, 4, 63-80, doi:10.1007/s11306-0070093-z, 2008.

Edney, E. O., Kleindienst, T. E., Jaoui, M., Lewandowski, M., Offenberg, J. H., Wang, W., and Claeys, M.: Formation of 2methyl tetrols and 2-methylglyceric acid in secondary organic aerosol from laboratory irradiated isoprene/NOX/SO 2 /air mixtures and their detection in ambient $\mathrm{PM}_{2} .5$ samples collected in the eastern United States, Atmos. Environ., 39, 5281-5289, doi:10.1016/j.atmosenv.2005.05.031, 2005.

Ehn, M., Kleist, E., Junninen, H., Petäjä, T., Lönn, G., Schobesberger, S., Dal Maso, M., Trimborn, A., Kulmala, M., Worsnop, D. R., Wahner, A., Wildt, J., and Mentel, Th. F.: Gas phase formation of extremely oxidized pinene reaction products in chamber and ambient air, Atmos. Chem. Phys., 12, 5113-5127, doi:10.5194/acp-12-5113-2012, 2012.

Ehn, M., Thornton, J. A., Kleist, E., Sipilä, M., Junninen, H., Pullinen, I., Springer, M., Rubach, F., Tillmann, R., Lee, B., Lopez-Hilfiker, F., Andres, S., Acir, I., Rissanen, M., Jokinen, T., Schobesberger, S., Kangasluoma, J., Kontkanen, J., Nieminen, T., Kurtén, T., Nielsen, L. B., Jørgensen, S., Kjaergaard, H. G., Canagaratna, M., Maso, M. D., Berndt, T., Petäjä, T., Wahner, A., Kerminen, V., Kulmala, M., Worsnop, D. R., Wildt, J., and Mentel, T. F.: A large source of low-volatility secondary organic aerosol., Nature, 506, 476-479, doi:10.1038/nature13032, 2014.

Eiceman, G. A., Karpas, Z., and Herbert H. Hill, J.: Ion Mobility Spectrometry, Third Edition, CRC Press, Boca Raton, FL, 444 pp., ISBN-13: 9781439859971, 2013.

Eisele, F. and Tanner, D.: Measurement of the gas phase concentration of $\mathrm{H}_{2} \mathrm{SO}_{4}$ and methane sulfonic acid and estimates of $\mathrm{H}_{2} \mathrm{SO}_{4}$ production and loss in the atmosphere, J. Geophys. Res., 98, 9001-9010, doi:10.1029/93JD00031, 1993.

Fernandez-Lima, F. A., Becker, C., McKenna, A. M., Rodgers, R. P., Marshall, A. G., and Russell, D. H.: Petroleum Crude Oil Characterization by IMS-MS and FTICR MS, Anal. Chem., 81, 9941-9947, doi:10.1021/ac901594f, 2009.

Fernández-Maestre, R., Harden, C. S., Ewing, R. G., Crawford, C. L., and Hill, H. H.: Chemical standards in ion mobility spectrometry, Analyst, 135, 1433, doi:10.1039/b915202d, 2010.

Galloway, M. M., Chhabra, P. S., Chan, A. W. H., Surratt, J. D., Flagan, R. C., Seinfeld, J. H., and Keutsch, F. N.: Glyoxal uptake on ammonium sulphate seed aerosol: reaction products and reversibility of uptake under dark and irradiated conditions, Atmos. Chem. Phys., 9, 3331-3345, doi:10.5194/acp-9-3331-2009, 2009.

Gao, S., Keywood, M., Ng, N. L., Surratt, J., Varutbangkul, V., Bahreini, R., Flagan, R. C., and Seinfeld, J. H.: Low-MolecularWeight and Oligomeric Components in Secondary Organic Aerosol from the Ozonolysis of Cycloalkenes and $\alpha$-Pinene, J. Phys. Chem. A, 108, 10147-10164, doi:10.1021/jp047466e, 2004.

Gaston, C. J., Riedel, T. P., Zhang, Z., Gold, A., Surratt, J. D., and Thornton, J. A.: Reactive uptake of an isoprene-derived epoxydiol to submicron aerosol particles., Environ. Sci. Technol., 48, 11178-11186, doi:10.1021/es5034266, 2014.

Glasius, M., Duane, M., and Larsen, B. R.: Determination of polar terpene oxidation products in aerosols by liquid chromatography-ion trap mass spectrometry, J. Chromatogr. A 833, 121-135, doi:10.1016/S0021-9673(98)01042-5, 1999.

Goldstein, A. H. and Galbally, I. E.: Known and Unexplored Organic Constituents in the Earth's Atmosphere, Environ. Sci. Technol., 41, 1514-1521, doi:10.1021/es072476p, 2007.

Gómez-González, Y., Surratt, J. D., Cuyckens, F., Szmigielski, R., Vermeylen, R., Jaoui, M., Lewandowski, M., Offenberg, J. H., Kleindienst, T. E., Edney, E. O., Blockhuys, F., Van Alsenoy, C., Maenhaut, W., and Claeys, M.: Characterization of organosulfates from the photooxidation of isoprene and unsaturated fatty acids in ambient aerosol using liquid chromatography/(-) electrospray ionization mass spectrometry, J. Mass Spectrom., 43, 371-382, doi:10.1002/jms.1329, 2008.

Groessl, M., Graf, S., and Knochenmuss, R.: High resolution ion mobility-mass spectrometry for separation and identification of isomeric lipids, Analyst, 140, 6904-6911, doi:10.1039/c5an00838g, 2015.

Guenther, A., Nicholas, C., Erickson, D., Fall, R., Geron, C., Gradel, T., Harley, P., Klinger, L., Lerdau, M., Mckay, W. A., Pierce, T., Scholes, B., Steinbrecher, R., Tallamraju, R., Taylor, J., and Zimmerman, P.: A global model of natural volatile organic compound emissions, J. Geophys. Res., 100, 8873-8892, 1995.

Hallquist, M., Wenger, J. C., Baltensperger, U., Rudich, Y., Simpson, D., Claeys, M., Dommen, J., Donahue, N. M., George, C., Goldstein, A. H., Hamilton, J. F., Herrmann, H., Hoffmann, T., Iinuma, Y., Jang, M., Jenkin, M. E., Jimenez, J. L., Kiendler-Scharr, A., Maenhaut, W., McFiggans, G., Mentel, Th. F., Monod, A., Prévôt, A. S. H., Seinfeld, J. H., Surratt, J. D., Szmigielski, R., and Wildt, J.: The formation, properties and impact of secondary organic aerosol: current and emerging issues, Atmos. Chem. Phys., 9, 5155-5236, doi:10.5194/acp-9-51552009, 2009.

Hettiyadura, A. P. S., Stone, E. A., Kundu, S., Baker, Z., Geddes, E., Richards, K., and Humphry, T.: Determination of atmospheric organosulfates using HILIC chromatography with MS detection, Atmos. Meas. Tech., 8, 2347-2358, doi:10.5194/amt8-2347-2015, 2015.

Hidy, G. M., Blanchard, C. L., Baumann, K., Edgerton, E., Tanenbaum, S., Shaw, S., Knipping, E., Tombach, I., Jansen, J., and Walters, J.: Chemical climatology of the southeastern United States, 1999-2013, Atmos. Chem. Phys., 14, 11893-11914, doi:10.5194/acp-14-11893-2014, 2014.

Horning, E. C., Carroll, D. I., Dzidic, I., Lin, S.-N., Stillwell, R. N., and Thenot, J.-P.: Atmospheric pressure ionization mass spectrometry, J. Chromatogr. A, 142, 481-495, doi:10.1016/S00219673(01)92061-8, 1977.

Hyttinen, N., Kupiainen-Määttä, O., Rissanen, M. P., Muuronen, M., Ehn, M., and Kurtén, T.: Modeling the Charging of Highly Oxidized Cyclohexene Ozonolysis Products Using Nitrate-Based Chemical Ionization, J. Phys. Chem. A, 119, 6339-6345, doi:10.1021/acs.jpca.5b01818, 2015.

Iinuma, Y., Böge, O., Gnauk, T., and Herrmann, H.: Aerosolchamber study of the $\alpha$-pinene/ $\mathrm{O}_{3}$ reaction: influence of particle acidity on aerosol yields and products, Atmos. Environ., 38, 761-773, doi:10.1016/j.atmosenv.2003.10.015, 2004.

Jarrold, M. F.: Peptides and Proteins in the Vapor Phase, Annu. Rev. Phys. Chem., 51, 179-207, doi:10.1146/annurev.physchem.51.1.179, 2000. 
Jokinen, T., Sipilä, M., Junninen, H., Ehn, M., Lönn, G., Hakala, J., Petäjä, T., Mauldin III, R. L., Kulmala, M., and Worsnop, D. R.: Atmospheric sulphuric acid and neutral cluster measurements using CI-APi-TOF, Atmos. Chem. Phys., 12, 4117-4125, doi:10.5194/acp-12-4117-2012, 2012.

Jokinen, T., Sipilä, M., Richters, S., Kerminen, V.-M., Paasonen, P., Stratmann, F., Worsnop, D., Kulmala, M., Ehn, M., Herrmann, H., and Berndt, T.: Rapid Autoxidation Forms Highly Oxidized RO2 Radicals in the Atmosphere, Angew. Chemie Int. Ed., 53, 14596-14600, doi:10.1002/anie.201408566, 2014.

Jokinen, T., Berndt, T., Makkonen, R., Kerminen, V., Junninen, H., Paasonen, P., Stratmann, F., Herrmann, H., Guenther, A. B., Worsnop, D. R., Kulmala, M., Ehn, M., and Sipilä, M.: Production of extremely low volatile organic compounds from biogenic emissions: Measured yields and atmospheric implications, P. Natl. Acad. Sci. USA, 112, 7123-7128, doi:10.1073/pnas.1423977112, 2015.

Kang, E., Root, M. J., Toohey, D. W., and Brune, W. H.: Introducing the concept of Potential Aerosol Mass (PAM), Atmos. Chem. Phys., 7, 5727-5744, doi:10.5194/acp-7-5727-2007, 2007.

Kanu, A., Dwivedi, P., Tam, M., Metz, L., and Hill, H. H.: Ion mobility-mass spectrometry, J. Mass Spectrom., 43, 1-22, doi:10.1002/jms.1383, 2008.

Kaplan, K., Graf, S., Tanner, C., Gonin, M., Fuhrer, K., Knochenmuss, R., Dwivedi, P., and Hill, H. H.: Resistive Glass IMTOFMS, Anal. Chem., 82, 9336-9343, doi:10.1021/ac1017259, 2010.

Karasek, F. W.: Plasma chromatography, Anal. Chem., 46, 710A720A, doi:10.1021/ac60344a053, 1974.

Knochenmuss, R., Graf, S., Fuhrer, K., and Gonin, M.: Multiplexed High Pressure Ion Mobility-TOFMS: High Resolution, Sensitivity and Structural Information in One Package, in Proceedings of the 61st ASMS Conference on Mass Spectrometry and Allied Topics, p. WP745., 9-13 June 2013.

Krechmer, J. E., Coggon, M. M., Massoli, P., Nguyen, T. B., Crounse, J. D., Hu, W., Day, D. A., Tyndall, G. S., Henze, D. K., Rivera-Rios, J. C., Nowak, J. B., Kimmel, J. R., Mauldin, R. L., Stark, H., Jayne, J. T., Sipilä, M., Junninen, H., Clair, J. M. St., Zhang, X., Feiner, P. A., Zhang, L., Miller, D. O., Brune, W. H., Keutsch, F. N., Wennberg, P. O., Seinfeld, J. H., Worsnop, D. R., Jimenez, J. L., and Canagaratna, M. R.: Formation of low volatility organic compounds and secondary organic aerosol from isoprene hydroxyhydroperoxide low-NO oxidation, Environ. Sci. Technol., 49, 10330-10339, doi:10.1021/acs.est.5b02031, 2015.

Kroll, J. H., Ng, N. L., Murphy, S. M., Flagan, R. C., and Seinfeld, J. H.: Secondary Organic Aerosol Formation from Isoprene Photooxidation, Environ. Sci. Technol., 40, 1869-1877, doi:10.1021/es0524301, 2006.

Kückelmann, U., Warscheid, B., and Hoffmann, T.: On-Line Characterization of Organic Aerosols Formed from Biogenic Precursors Using Atmospheric Pressure Chemical Ionization Mass Spectrometry, Anal. Chem., 72, 1905-1912, doi:10.1021/ac991178a, 2000.

Kulmala, M., Kontkanen, J., Junninen, H., Lehtipalo, K., Manninen, H. E., Nieminen, T., Petäjä, T., Sipilä, M., Schobesberger, S., Rantala, P., Franchin, A., Jokinen, T., Järvinen, E., Äijälä, M., Kangasluoma, J., Hakala, J., Aalto, P. P., Paasonen, P., Mikkilä, J., Vanhanen, J., Aalto, J., Hakola, H., Makkonen, U., Ruuskanen, T., Mauldin, R. L., Duplissy, J., Vehkamäki, H., Bäck,
J., Kortelainen, A., Riipinen, I., Kurtén, T., Johnston, M. V, Smith, J. N., Ehn, M., Mentel, T. F., Lehtinen, K. E. J., Laaksonen, A., Kerminen, V.-M., and Worsnop, D. R.: Direct observations of atmospheric aerosol nucleation., Science, 339, 943-946, doi:10.1126/science.1227385, 2013.

Lambe, A. T., Ahern, A. T., Williams, L. R., Slowik, J. G., Wong, J. P. S., Abbatt, J. P. D., Brune, W. H., Ng, N. L., Wright, J. P., Croasdale, D. R., Worsnop, D. R., Davidovits, P., and Onasch, T. B.: Characterization of aerosol photooxidation flow reactors: heterogeneous oxidation, secondary organic aerosol formation and cloud condensation nuclei activity measurements, Atmos. Meas. Tech., 4, 445-461, doi:10.5194/amt-4-445-2011, 2011.

Lee, B. H., Mohr, C., Lopez-Hilfiker, F. D., Lutz, A., Hallquist, M., Lee, L., Romer, P., Cohen, R. C., Iyer, S., Kurtén, T., Hu, W., Day, D. A., Campuzano-Jost, P., Jimenez, J. L., Xu, L., Ng, N. L., Guo, H., Weber, R. J., Wild, R. J., Brown, S. S., Koss, A., de Gouw, J., Olson, K., Goldstein, A. H., Seco, R., Kim, S., McAvey, K., Shepson, P. B., Starn, T., Baumann, K., Edgerton, E. S., Liu, J., Shilling, J. E., Miller, D. O., Brune, W., Schobesberger, S., D'Ambro, E. L., and Thornton, J. A.: Highly functionalized organic nitrates in the southeast United States: Contribution to secondary organic aerosol and reactive nitrogen budgets, P. Natl. Acad. Sci. USA, 113, 1516-1521, doi:10.1073/pnas.1508108113, 2016.

Lin, Y., Zhang, Z., Docherty, K. S., Zhang, H., Budisulistiorini, S. H., Rubitschun, C. L., Shaw, S. L., Knipping, E. M., Edgerton, E. S., Kleindienst, T. E., Gold, A., and Surratt, J. D.: Isoprene Epoxydiols as Precursors to Secondary Organic Aerosol Formation: Acid-Catalyzed Reactive Uptake Studies with Authentic Compounds, Environ. Sci. Technol., 46, 250258, doi:10.1021/es202554c, 2012.

Lin, Y.-H., Zhang, H., Pye, H. O. T., Zhang, Z., Marth, W. J., Park, S., Arashiro, M., Cui, T., Budisulistiorini, S. H., Sexton, K. G., Vizuete, W., Xie, Y., Luecken, D. J., Piletic, I. R., Edney, E. O., Bartolotti, L. J., Gold, A., and Surratt, J. D.: Epoxide as a precursor to secondary organic aerosol formation from isoprene photooxidation in the presence of nitrogen oxides, P. Natl. Acad. Sci USA, 110, 6718-6723, doi:10.1073/pnas.1221150110, 2013.

Lin, Y.-H., Budisulistiorini, S. H., Chu, K., Siejack, R. A., Zhang, H., Riva, M., Zhang, Z., Gold, A., Kautzman, K. E., and Surratt, J. D.: Light-absorbing oligomer formation in secondary organic aerosol from reactive uptake of isoprene epoxydiols, Environ. Sci. Technol., 48, 12012-12021, doi:10.1021/es503142b, 2014.

Lopez-Hilfiker, F. D., Mohr, C., Ehn, M., Rubach, F., Kleist, E., Wildt, J., Mentel, Th. F., Lutz, A., Hallquist, M., Worsnop, D., and Thornton, J. A.: A novel method for online analysis of gas and particle composition: description and evaluation of a Filter Inlet for Gases and AEROsols (FIGAERO), Atmos. Meas. Tech., 7, 983-1001, doi:10.5194/amt-7-983-2014, 2014.

Martinez, R. E., Williams, B. J., Zhang, Y., Hagan, D., Walker, M., Kreisberg, N. M., Hering, S. V., Hohaus, T., Jayne, J. T., and Worsnop, D. R.: Development of a volatility and polarity separator (VAPS) for volatility- and polarity-resolved organic aerosol measurement, Aerosol Sci. Technol., 50, 255-271, doi:10.1080/02786826.2016.1147645, 2016.

Mason, E. A. and Schamp, H. W.: Mobility of gaseous lons in weak electric fields, Ann. Phys., 4, 233-270, doi:10.1016/00034916(58)90049-6, 1958. 
Mauldin, R. L., Tanner, D. J., and Eisele, F. L.: A new chemical ionization mass spectrometer technique for the fast measurement of gas phase nitric acid in the atmosphere, J. Geophys. Res. Atmos., 103, 3361-3367, doi:10.1029/97JD02212, 1998.

Mazzoleni, L. R., Saranjampour, P., Dalbec, M. M., Samburova, V., Hallar, A. G., Zielinska, B., Lowenthal, D. H., and Kohl, S.: Identification of water-soluble organic carbon in non-urban aerosols using ultrahigh-resolution FT-ICR mass spectrometry: organic anions, Environ. Chem., 9, 285, doi:10.1071/EN11167, 2012.

McDaniel, E. W. and Mason, E. A.: The mobility and diffusion of ions in gases, Book, 372 pp., ISBN-10: 0471583871, 1973.

McEwen, C. N. and Larsen, B. S.: Ionization mechanisms related to negative Ion APPI, APCI, and DART, J. Am. Soc. Mass Spectrom., 20, 1518-1521, doi:10.1016/j.jasms.2009.04.010, 2009.

McNaught, A. D. and Wilkinson, A.: IUPAC Compendium of Chemical Terminology, 2nd ed., the "Gold Book", edited by: Nic, M., Jirat, J., and Kosata, B., updates compiled by: Jenkins, A., Blackwell Scientific Publications, Oxford, ISBN-10: 09678550-9-8, doi:10.1351/goldbook, 2014.

Mentel, T. F., Springer, M., Ehn, M., Kleist, E., Pullinen, I., Kurtén, T., Rissanen, M., Wahner, A., and Wildt, J.: Formation of highly oxidized multifunctional compounds: autoxidation of peroxy radicals formed in the ozonolysis of alkenes - deduced from structure-product relationships, Atmos. Chem. Phys., 15, 67456765, doi:10.5194/acp-15-6745-2015, 2015.

Murphy, D. M., Cziczo, D. J., Froyd, K. D., Hudson, P. K., Matthew, B. M., Middlebrook, A. M., Peltier, R. E., Sullivan, A., Thomson, D. S., and Weber, R. J.: Single-particle mass spectrometry of tropospheric aerosol particles, J. Geophys. Res., 111, D23S32, doi:10.1029/2006JD007340, 2006.

Nozière, B., Kalberer, M., Claeys, M., Allan, J., D’Anna, B., Decesari, S., Finessi, E., Glasius, M., Grgić, I., Hamilton, J. F., Hoffmann, T., Iinuma, Y., Jaoui, M., Kahnt, A., Kampf, C. J., Kourtchev, I., Maenhaut, W., Marsden, N., Saarikoski, S., Schnelle-Kreis, J., Surratt, J. D., Szidat, S., Szmigielski, R., and Wisthaler, A.: The Molecular Identification of Organic Compounds in the Atmosphere: State of the Art and Challenges, Chem. Rev., 115, 3919-3983, doi:10.1021/cr5003485, 2015.

Olson, C. N., Galloway, M. M., Yu, G., Hedman, C. J., Lockett, M. R., Yoon, T., Stone, E. A., Smith, L. M., and Keutsch, F. N.: Hydroxycarboxylic acid-derived organosulfates: Synthesis, stability, and quantification in ambient aerosol, Environ. Sci. Technol., 45, 6468-6474, doi:10.1021/es201039p, 2011.

Paglia, G., Williams, J. P., Menikarachchi, L., Thompson, J. W., Tyldesley-Worster, R., Halldórsson, S., Rolfsson, O., Moseley, A., Grant, D., Langridge, J., Palsson, B. O., and Astarita, G.: Ion Mobility Derived Collision Cross Sections to Support Metabolomics Applications, Anal. Chem., 86, 3985-3993, doi:10.1021/ac500405x, 2014.

Paulot, F., Crounse, J. D., Kjaergaard, H. G., Kurten, A., St. Clair, J. M., Seinfeld, J. H., and Wennberg, P. O.: Supporting Online Material forUnexpected Epoxide Formation in the Gas-Phase Photooxidation of Isoprene, Science, 80, 730-733, doi:10.1126/science.1172910, 2009.

Rattanavaraha, W., Chu, K., Budisulistiorini, S. H., Riva, M., Lin, Y.-H., Edgerton, E. S., Baumann, K., Shaw, S. L., Guo, H., King, L., Weber, R. J., Neff, M. E., Stone, E. A., Offenberg, J. H., Zhang, Z., Gold, A., and Surratt, J. D.: Assessing the impact of anthropogenic pollution on isoprene-derived secondary organic aerosol formation in $\mathrm{PM}_{2.5}$ collected from the Birmingham, Alabama, ground site during the 2013 Southern Oxidant and Aerosol Study, Atmos. Chem. Phys., 16, 4897-4914, doi:10.5194/acp-16-4897-2016, 2016.

Revercomb, H. E. and Mason, E. A.: Theory of plasma chromatography/gaseous electrophoresis. Review, Anal. Chem., 47, 970983, doi:10.1021/ac60357a043, 1975.

Riedel, T. P., Lin, Y.-H., Budisulistiorini, S. H., Gaston, C. J., Thornton, J. a., Zhang, Z., Vizuete, W., Gold, A., and Surratt, J. D.: Heterogeneous Reactions of Isoprene-Derived Epoxides: Reaction Probabilities and Molar Secondary Organic Aerosol Yield Estimates, Environ. Sci. Technol. Lett., 2, 38-42, doi:10.1021/ez500406f, 2015.

Rissanen, M. P., Kurtén, T., Sipilä, M., Thornton, J. A., Kausiala, O., Garmash, O., Kjaergaard, H. G., Petäjä, T., Worsnop, D. R., Ehn, M., and Kulmala, M.: Effects of Chemical Complexity on the Autoxidation Mechanisms of Endocyclic Alkene Ozonolysis Products: From Methylcyclohexenes toward Understanding $\alpha$-Pinene, J. Phys. Chem. A, 119, 4633-4650, doi:10.1021/jp510966g, 2015

Riva, M., Budisulistiorini, S. H., Zhang, Z., Gold, A., and Surratt, J. D.: Chemical characterization of secondary organic aerosol constituents from isoprene ozonolysis in the presence of acidic aerosol, Atmos. Environ., 1, 1-9, doi:10.1016/j.atmosenv.2015.06.027, 2015.

Rivera-Rios, J. C., Nguyen, T. B., Crounse, J. D., Jud, W., St. Clair, J. M., Mikoviny, T., Gilman, J. B., Lerner, B. M., Kaiser, J. B., de Gouw, J., Wisthaler, A., Hansel, A., Wennberg, P. O., Seinfeld, J. H., and Keutsch, F. N.: Conversion of hydroperoxides to carbonyls in field and laboratory instrumentation: Observational bias in diagnosing pristine versus anthropogenically controlled atmospheric chemistry, Geophys. Res. Lett., 41, 86458651, doi:10.1002/2014GL061919, 2014.

Ruotolo, B. T., Benesch, J. L. P., Sandercock, A. M., Hyung, S.J., and Robinson, C. V: Ion mobility-mass spectrometry analysis of large protein complexes., Nat. Protoc., 3, 1139-1152, doi:10.1038/nprot.2008.78, 2008.

Siems, W. F., Viehland, L. A., and Hill, H. H.: Improved Momentum-Transfer Theory for Ion Mobility. 1. Derivation of the Fundamental Equation, Anal. Chem., 84, 9782-9791, doi:10.1021/ac301779s, 2012.

Spracklen, D. V., Jimenez, J. L., Carslaw, K. S., Worsnop, D. R., Evans, M. J., Mann, G. W., Zhang, Q., Canagaratna, M. R., Allan, J., Coe, H., McFiggans, G., Rap, A., and Forster, P.: Aerosol mass spectrometer constraint on the global secondary organic aerosol budget, Atmos. Chem. Phys., 11, 12109-12136, doi:10.5194/acp-11-12109-2011, 2011.

Stark, H., Yatavelli, R. L. N., Thompson, S. L., Kimmel, J. R., Cubison, M. J., Chhabra, P. S., Canagaratna, M. R., Jayne, J. T., Worsnop, D. R., and Jimenez, J. L.: Methods to extract molecular and bulk chemical information from series of complex mass spectra with limited mass resolution, Int. J. Mass Spectrom., 389, 26-38, doi:10.1016/j.ijms.2015.08.011, 2015.

St. Clair, J. M., Rivera-Rios, J. C., Crounse, J. D., Knap, H. C., Bates, K. H., Teng, A. P., Jørgensen, S., Kjaergaard, H. G., Keutsch, F. N., and Wennberg, P. O.: Kinetics and Products of the Reaction of the First-Generation Isoprene Hydroxy Hydroperoxide (ISOPOOH) with OH, J. Phys. Chem. A, 120, 1441-1451, doi:10.1021/acs.jpca.5b06532, 2016. 
Stone, E. A., Yang, L., Yu, L. E., and Rupakheti, M.: Characterization of organosulfates in atmospheric aerosols at Four Asian locations, Atmos. Environ., 47, 323-329, doi:10.1016/j.atmosenv.2011.10.058, 2012.

Surratt, J. D., Murphy, S. M., Kroll, J. H., Ng, N. L., Hildebrandt, L., Sorooshian, A., Szmigielski, R., Vermeylen, R., Maenhaut, W., Claeys, M., Flagan, R. C., and Seinfeld, J. H.: Chemical Composition of Secondary Organic Aerosol Formed from the Photooxidation of Isoprene, J. Phys. Chem. A, 110, 9665-9690, doi:10.1021/jp061734m, 2006.

Surratt, J. D., Kroll, J. H., Kleindienst, T. E., Edney, E. O., Claeys, M., Sorooshian, A., Ng, N. L., Offenberg, J. H., Lewandowski, M., Jaoui, M., Flagan, R. C., and Seinfeld, J. H.: Evidence for Organosulfates in Secondary Organic Aerosol, Environ. Sci. Technol., 41, 517-527, doi:10.1021/es062081q, 2007.

Surratt, J. D., Goìmez-Gonzaìlez, Y., Chan, A. W. H., Vermeylen, R., Shahgholi, M., Kleindienst, T. E., Edney, E. O., Offenberg, J. H., Lewandowski, M., Jaoui, M., Maenhaut, W., Claeys, M., Flagan, R. C., and Seinfeld, J. H.: Organosulfate Formation in Biogenic Secondary Organic Aerosol, J. Phys. Chem. A, 112, 8345-8378, doi:10.1021/jp802310p, 2008.

Surratt, J. D., Chan, A. W. H., Eddingsaas, N. C., Chan, M., Loza, C. L., Kwan, A. J., Hersey, S. P., Flagan, R. C., Wennberg, P. O., and Seinfeld, J. H.: Reactive intermediates revealed in secondary organic aerosol formation from isoprene, P. Natl. Acad. Sci. USA, 107, 6640-6645, doi:10.1073/pnas.0911114107, 2010.

Thomson, J. J.: Conduction of electricity through gases, Cambridge University Press, Cambridge, 566 pp., 1903.

Thompson, S. L., Yatavelli, R. L. N., Stark, H., Kimmel, J. R., Krechmer, J. E., Day, D. A., Isaacman-VanWertz, G., Yee, L., Goldstein, A. H., Khan, M. A. H., Holzinger, R., Kreisberg, N., Lopez-Hilfiker, F. D., Mohr, C., Thornton, J. A., Jayne, J. T., Canagaratna, M., Worsnop, D. R., and Jimenez, J. L.: Field intercomparison of the gas/particle partitioning of oxygenated organics during the Southern Oxidant and Aerosol Study (SOAS) in 2013, Aerosol Sci. Technol., submitted, 2015.

Tsigaridis, K., Daskalakis, N., Kanakidou, M., Adams, P. J., Artaxo, P., Bahadur, R., Balkanski, Y., Bauer, S. E., Bellouin, N., Benedetti, A., Bergman, T., Berntsen, T. K., Beukes, J. P., Bian, H., Carslaw, K. S., Chin, M., Curci, G., Diehl, T., Easter, R. C., Ghan, S. J., Gong, S. L., Hodzic, A., Hoyle, C. R., Iversen, T., Jathar, S., Jimenez, J. L., Kaiser, J. W., Kirkevåg, A., Koch, D., Kokkola, H., Lee, Y. H., Lin, G., Liu, X., Luo, G., Ma, X., Mann, G. W., Mihalopoulos, N., Morcrette, J.-J., Müller, J.-F., Myhre, G., Myriokefalitakis, S., Ng, N. L., O’Donnell, D., Penner, J. E., Pozzoli, L., Pringle, K. J., Russell, L. M., Schulz, M., Sciare, J., Seland, Ø., Shindell, D. T., Sillman, S., Skeie, R. B., Spracklen, D., Stavrakou, T., Steenrod, S. D., Takemura, T., Tiitta, P., Tilmes, S., Tost, H., van Noije, T., van Zyl, P. G., von Salzen, K., Yu, F., Wang, Z., Wang, Z., Zaveri, R. A., Zhang, H., Zhang, K., Zhang, Q., and Zhang, X.: The AeroCom evaluation and intercomparison of organic aerosol in global models, Atmos. Chem. Phys., 14, 10845-10895, doi:10.5194/acp-1410845-2014, 2014.
Veres, P., Roberts, J. M., Warneke, C., Welsh-Bon, D., Zahniser, M., Herndon, S., Fall, R., and de Gouw, J.: Development of negative-ion proton-transfer chemical-ionization mass spectrometry (NI-PT-CIMS) for the measurement of gas-phase organic acids in the atmosphere, Int. J. Mass Spectrom., 274, 48-55, doi:10.1016/j.ijms.2008.04.032, 2008.

Vogel, A. L., Äijälä, M., Corrigan, A. L., Junninen, H., Ehn, M., Petäjä, T., Worsnop, D. R., Kulmala, M., Russell, L. M., Williams, J., and Hoffmann, T.: In situ submicron organic aerosol characterization at a boreal forest research station during HUMPPA-COPEC 2010 using soft and hard ionization mass spectrometry, Atmos. Chem. Phys., 13, 10933-10950, doi:10.5194/acp-13-10933-2013, 2013.

Williams, B. J., Zhang, Y., Zuo, X., Martinez, R. E., Walker, M. J., Kreisberg, N. M., Goldstein, A. H., Docherty, K. S., and Jimenez, J. L.: Organic and inorganic decomposition products from the thermal desorption of atmospheric particles, Atmos. Meas. Tech., 9, 1569-1586, doi:10.5194/amt-9-1569-2016, 2016.

Zare, R. N., Fernández, F. M., and Kimmel, J. R.: Hadamard Transform Time-of-Flight Mass Spectrometry: More Signal, More of the Time, Angew. Chemie Int. Ed., 42, 30-35, doi:10.1002/anie.200390047, 2003.

Zhang, Q., Jimenez, J. L., Canagaratna, M. R., Allan, J. D., Coe, H., Ulbrich, I., Alfarra, M. R., Takami, A., Middlebrook, a. M., Sun, Y. L., Dzepina, K., Dunlea, E., Docherty, K., DeCarlo, P. F., Salcedo, D., Onasch, T., Jayne, J. T., Miyoshi, T., Shimono, A., Hatakeyama, S., Takegawa, N., Kondo, Y., Schneider, J., Drewnick, F., Borrmann, S., Weimer, S., Demerjian, K., Williams, P., Bower, K., Bahreini, R., Cottrell, L., Griffin, R. J., Rautiainen, J., Sun, J. Y., Zhang, Y. M., and Worsnop, D. R.: Ubiquity and dominance of oxygenated species in organic aerosols in anthropogenically-influenced Northern Hemisphere midlatitudes, Geophys. Res. Lett., 34, L13801, doi:10.1029/2007GL029979, 2007.

Zhang, X., Knochenmuss, R., Siems, W. F., Liu, W., Graf, S., and Hill, H. H.: Evaluation of Hadamard Transform Atmospheric Pressure Ion Mobility Time-of-Flight Mass Spectrometry for Complex Mixture Analysis., Anal. Chem., 86, 1661-1670, doi:10.1021/ac403435p, 2014.

Zhang, Z., Lin, Y.-H., Zhang, H., Surratt, J. D., Ball, L. M., and Gold, A.: Technical Note: Synthesis of isoprene atmospheric oxidation products: isomeric epoxydiols and the rearrangement products cis- and trans-3-methyl-3,4-dihydroxytetrahydrofuran, Atmos. Chem. Phys., 12, 8529-8535, doi:10.5194/acp-12-85292012, 2012. 